\title{
Sulfur isotope and trace element systematics of zoned pyrite crystals from the El Indio Au-Cu-Ag deposit, Chile
}

\author{
Dominique Tanner ${ }^{1,2}\left(\mathbb{D} \cdot\right.$ Richard W. Henley $^{1} \cdot$ John A. Mavrogenes ${ }^{1} \cdot$ Peter Holden $^{1}$
}

Received: 14 September 2015 / Accepted: 2 March 2016 / Published online: 25 March 2016

(C) The Author(s) 2016. This article is published with open access at Springerlink.com

\begin{abstract}
We present a comparative study between early, massive pyrite preceding $(\mathrm{Cu}-\mathrm{Ag})$ sulfosalt mineralization in high-temperature feeder zones ('early pyrite') and late pyrite that formed during silicic alteration associated with Au deposition ('late pyrite') at the El Indio high-sulfidation $\mathrm{Au}-\mathrm{Ag}-\mathrm{Cu}$ deposit, Chile. We use coupled in situ sulfur isotope and trace element analyses to chronologically assess geochemical variations across growth zones in these pyrite crystals. Early pyrite that formed in high-temperature feeder zones shows intricate oscillatory zonation of $\mathrm{Cu}$, with individual laminae containing up to $1.15 \mathrm{wt} \% \mathrm{Cu}$ and trace $\mathrm{Co}, \mathrm{As}, \mathrm{Bi}, \mathrm{Ni}, \mathrm{Zn}, \mathrm{Se}, \mathrm{Ag}, \mathrm{Sb}, \mathrm{Te}, \mathrm{Au}, \mathrm{Pb}$ and $\mathrm{Bi}$. Late pyrite formed after $(\mathrm{Cu}-\mathrm{Ag})$ sulfosalt mineralization. It contains up to $1.14 \mathrm{wt} \%$ As with trace $\mathrm{Cu}, \mathrm{Zn}, \mathrm{Pb}$, $\mathrm{V}, \mathrm{Mn}, \mathrm{Co}, \mathrm{Ni}, \mathrm{Ge}, \mathrm{Se}, \mathrm{Ag}, \mathrm{Sb}, \mathrm{Te}, \mathrm{Pb}$ and $\mathrm{Bi}$, as well as colloform $\mathrm{Cu}$-rich growth bands containing vugs toward the outer edges of some crystals. Plotting the trace element data in chronological order (i.e., from core to rim) revealed that $\mathrm{Co}$ and $\mathrm{Ni}$ were the only elements to consistently covary across growth zones. Other trace elements were coupled in specific growth zones, but did not consistently covary across any individual crystal. The $\delta^{34} \mathrm{~S}$ of early pyrite
\end{abstract}

Communicated by Steven Reddy.

Electronic supplementary material The online version of this article (doi:10.1007/s00410-016-1248-6) contains supplementary material, which is available to authorized users.

Dominique Tanner

dom.tanner@gmail.com; TannerD@ cardiff.ac.uk

1 Research School of Earth Sciences, Australian National University, Canberra, ACT 0200, Australia

2 School of Earth and Ocean Sciences, Cardiff University, Main Building, Park Place, Cardiff CF10 3AT, UK crystals in high-temperature feeder zones range from -3.19 to $1.88 \%$ o $( \pm 0.5 \%$ ) , consistent with sublimation directly from a high-temperature magmatic vapor phase. Late pyrite crystals are distinctly more enriched in $\delta^{34} \mathrm{~S}$ than early pyrite $\left(\delta^{34} \mathrm{~S}=0.05-4.77 \%\right.$, $\pm 0.5 \%$ ) , as a consequence of deposition from a liquid phase at lower temperatures. It is unclear whether the late pyrite was deposited from a small volume of liquid condensate, or a larger volume of hydrothermal fluid. Both types of pyrite exhibit intracrystalline $\delta^{34} \mathrm{~S}$ variation, with a range of up to $3.31 \%$ recorded in an early pyrite crystal and up to $4.48 \%$ in a late pyrite crystal. Variations in $\delta^{34} S_{\text {pyrite }}$ at El Indio did not correspond with changes in trace element geochemistry. The lack of correlation between trace elements and $\delta^{34} \mathrm{~S}$, as well as the abundance of microscale mineral inclusions and vugs in El Indio pyrite indicate that the trace element content of pyrite at El Indio is largely controlled by nanoscale, syndepositional mineral inclusions. Co and $\mathrm{Ni}$ were the only elements partitioned within the crystal structure of pyrite. $\mathrm{Cu}$-rich oscillatory zones in early pyrite likely formed by nanoscale inclusions of $\mathrm{Cu}$-rich sulfosalts or chalcopyrite, evidence of deposition from a fluid cyclically saturated in ore metals. This process may be restricted to polymetallic high-sulfidation-like deposits.

Keywords Pyrite - High-sulfidation - Trace element . Sulfur isotope $\cdot$ LA-ICP-MS $\cdot$ SHRIMP $\cdot$ Zonation

\section{Introduction}

Pyrite is ubiquitous in many types of hydrothermal ore deposits. The texture and geochemistry of pyrite have been used extensively in unraveling the genesis of many ore deposits. For example, the texture, habit and morphology 
of pyrite can record replacement or dissolution and can also be used to distinguish between supersaturation events, near-equilibrium crystallization or recrystallization (e.g., Craig et al. 1998; Alonso-Azcarate et al. 2001; Franchini et al. 2015). The trace element geochemistry of pyrite and included nanoparticles may reveal changes in the $\mathrm{pH}$, oxidation state and source of the ore-forming fluid (e.g., Huston et al. 1995; Chouinard et al. 2005; Barker et al. 2009; Deditius et al. 2011). The sulfur isotope composition of pyrite can be used to evaluate physicochemical conditions during deposition and provides an alternative technique to identify fluid source(s) or fluid mixing (e.g., Madyagan et al. 2013; Xue et al. 2013).

Recent advances in in situ microanalytical techniques permit us to probe the chemistry of individual growth bands in minerals and thus record geochemical variations between the core and rim of a crystal. This ability to track temporal change within the crystallization histories of individual minerals provides us with a chronological framework that we can link with geochemical data to ascertain the genetic evolution of ore fluids. Pyrite is an ideal mineral for linked trace element and isotopic studies as: (1) pyrite is ubiquitous in hydrothermal ore deposits and often present in multiple stages of paragenesis, (2) pyrite has a simple stoichiometry, (3) isotopic fractionation factors for pyrite are well established (e.g., Ohmoto and Rye 1979), and (4) pyrite preserves distinctive chemical zonation.

Despite the extensive literature on trace element and sulfur isotope data in pyrite, only a few studies provide coupled trace element and sulfur isotope analyses on pyrite crystals in situ. These include studies of zoned pyrite crystals from the West Banshee and Turquoise Ridge Carlin-style Au deposit (Barker et al. 2009), the Porgera fault-valve Au deposit (Peterson and Mavrogenes 2014), the Pardo volcanogenic-hosted massive sulfide Au deposit (Ulrich et al. 2011), the Wallaby lode-Au deposit (Murray 2011) and the Chu-Sarysu roll-front U deposit (Lach et al. 2015). Of these studies, those focusing on hydrothermal $\mathrm{Au}$ deposition (Barker et al. 2009; Peterson and Mavrogenes 2014; Murray 2011) show a clear relationship between trace element geochemistry and $\delta^{34} \mathrm{~S}_{\text {pyrite }}$, which they interpret as a record of changes in fluid chemistry related to mineralization processes.

Here, we use these newly available in situ microanalytical techniques to compare changes in sulfur isotope ratios and trace element abundances between early massive pyrite veins that precede $\mathrm{Cu}-\mathrm{Ag}$ sulfosalt mineralization and paragenetically later silicic veins that contain pyrite, sulfosalts and high-grade $\mathrm{Ag}-\mathrm{Au}$ mineralization at the El Indio $\mathrm{Au}-\mathrm{Cu}-\mathrm{Ag}$ deposit, Chile. This is the first study to compare in situ sulfur isotope and trace element geochemistry in pyrite from a high-sulfidation deposit.

\section{Geology of the EI Indio Au-Ag-Cu high-sulfidation deposit}

The El Indio $\mathrm{Au}-\mathrm{Ag}-\mathrm{Cu}$ high-sulfidation deposit is located $500 \mathrm{~km}$ north of Santiago in the high Andes near the Chilean-Argentinian border (Jannas et al. 1990; Henley et al. 2012). The principal ore minerals are enargite $\left(\mathrm{Cu}_{3} \mathrm{AsS}_{4}\right)$, tennantite $\left(\mathrm{Cu}_{6}\left[\mathrm{Cu}_{4}(\mathrm{Fe}, \mathrm{Zn})_{2}\right] \mathrm{As}_{4} \mathrm{~S}_{13}\right)$ and native $\mathrm{Au}$, hosted in a complex network of veins within a sequence of altered ignimbrites and brecciated tuffs (Jannas et al. 1990).

Sulfide mineralization at El Indio occurred at $\sim 7 \mathrm{Ma}$, beneath a dacitic volcanic complex (Jannas et al. 1999). The deposit is hosted within $30-40 \mathrm{~km}^{2}$ of andesitic to dacitic volcanic rocks overprinted by advanced argillic to argillic alteration. Within this region, vein mineralization is restricted to an area $\sim 2 \mathrm{~km}^{2}$ hosted within a syn-volcanic array of faults and fractures that overprint wallrock alteration and silicification (Fig. 1) (Berger and Henley 2011; Henley et al. 2012).

The sequence of vein mineralization at El Indio can be broken down into three genetic stages (Fig. 2): (1) pre-ore massive pyrite vein filling ('early pyrite'); (2) enargitetennantite mineralization (containing up to $10 \% \mathrm{Cu}$ and 120 ppm Ag), followed by; and (3) 'Au-stage' (>100 ppm $\mathrm{Au})$ quartz-pyrite-sulfosalt veins (containing 'late pyrite') (Jannas et al. 1990; Deyell et al. 2004).

\section{Paragenesis of 'early pyrite' veins}

Jannas et al. (1990, 1999) observed that massive enargite and pyrite fill 'Cu-stage' veins; however, Henley et al. (2012) clarify that deposition of massive pyrite veins preceded sulfosalt mineralization at El Indio, as veins of sulfosalt fill fractures crosscutting massive pyrite. Hence, we refer to this massive pyrite as 'early pyrite,' Sulfosalt phase relations and trace element chemistry suggest that sulfosalt assemblages condensed from one-phase magmatic vapor ${ }^{1}$ above $665{ }^{\circ} \mathrm{C}$ and below $694{ }^{\circ} \mathrm{C}$ (the melting point of the crystalline enargite that precedes $\mathrm{Fe}$-tennantite) (Henley et al. 2012). Since the stability limit of pyrite is $742^{\circ} \mathrm{C}$ and no major break in the paragenetic sequence is observed, it is reasonable to conclude that pyrite deposition occurred between 665 and $742{ }^{\circ} \mathrm{C}$. As quartz deposition did not occur during this paragenetic stage (Fig. 2), no fluid inclusion data or $\mathrm{Ti}$ in quartz temperature estimates are available.

\footnotetext{
${ }^{1}$ We use the generic term magmatic vapor to describe a gas phase released from subvolcanic magmatic systems. As described elsewhere (e.g., Henley and Berger 2011a), magmatic gases expand as they ascend through the crust via fracture networks.
} 

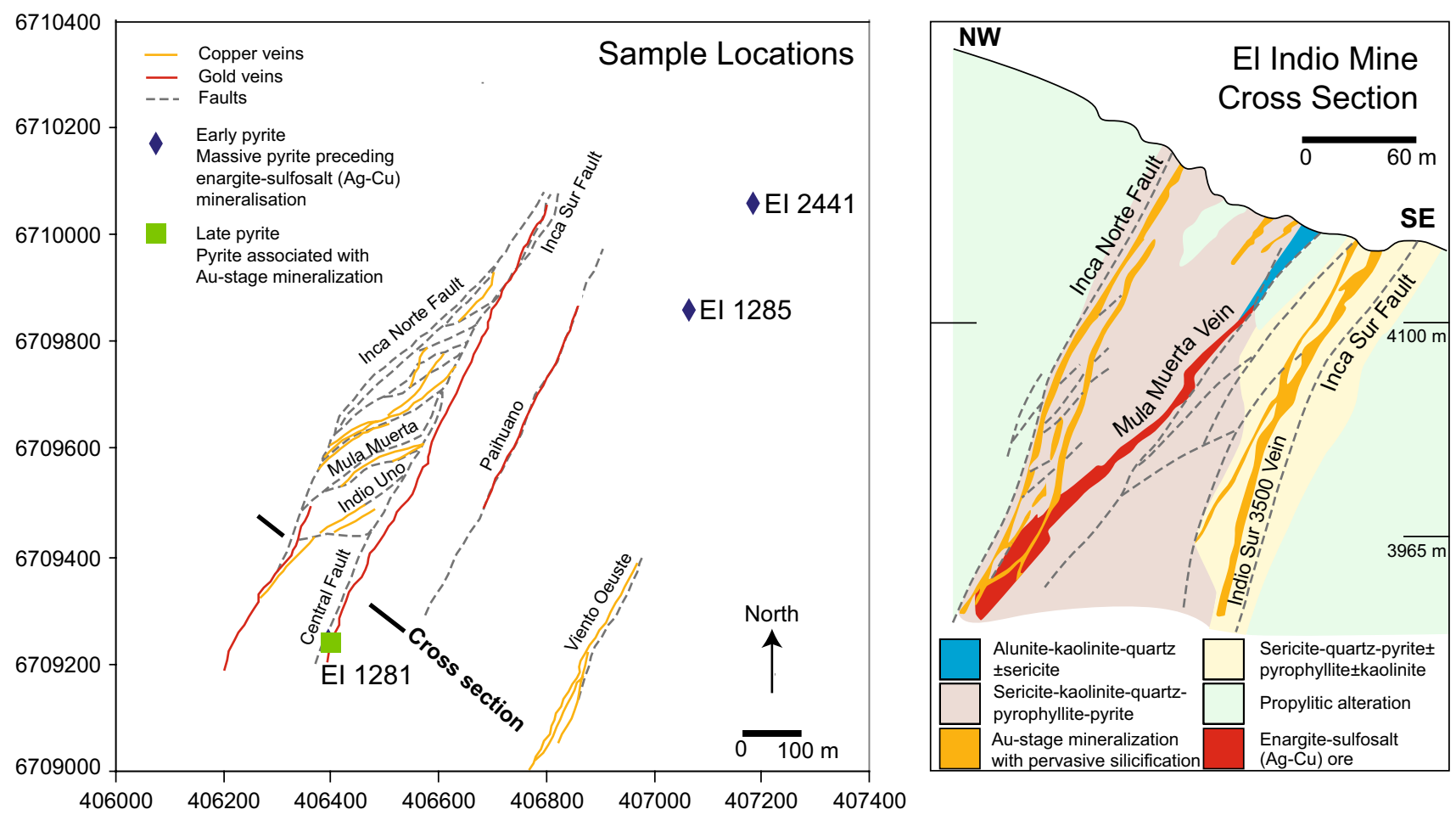

Fig. 1 Left Map of the El Indio deposit, showing the location of the samples used in this study. Note the location of the cross section. Right simplified NW-SE cross section of the El Indio mine showing alteration and mineralization. Modified from Henley et al. 2012

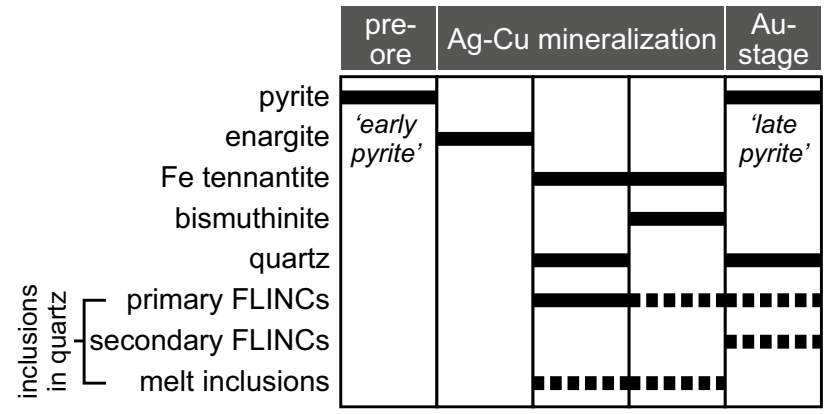

Fig. 2 Simplified paragenesis of the El Indio $\mathrm{Au}-\mathrm{Cu}-\mathrm{Ag}$ deposit for samples used in this study, highlighting the difference between 'early pyrite' preceding sulfosalt deposition and 'late pyrite' associated with silica alteration (modified from Tanner et al. 2015 and Jannas et al. 1999). FLINCs fluid inclusions

Paragenesis of enargite-tennantite mineralization: Enargite-tennantite mineralization is thought to have formed between 650 and $1150 \mathrm{~m}$ below the paleosurface in a dacitic volcanic complex (Jannas et al. 1999; Henley et al. 2012). Enargite-tennantite mineralization is associated with sericite-kaolinite-quartz-pyrophyllite-pyrite alteration below $4000 \mathrm{~m} \mathrm{asl}^{2}$ depth in the mine (Jannas

\footnotetext{
$\overline{2}$ Above sea level.
}

et al. 1999). Above $4000 \mathrm{~m}$ asl depth, mineralization was preceded by alunite-kaolinite-quartz wallrock alteration, and alunite was destroyed during deposition of enargite and tennantite (Jannas et al. 1999). Henley et al. (2012) further divided the deposition of enargite-tennantite veins into three paragenetic sequences:

(1) rupturing of early pyrite veins accompanied by local deposition of crystalline enargite in open space cavities;

(2) corrosion of pyrite and enargite by $\mathrm{Fe}-$ tennantite interpreted as As-rich sulfosalt melts, and quartz (interpreted as evolved silica hydrate deposited from a $\mathrm{SiO}_{2}-$ supersaturated fluid; Tanner et al. 2015); and

(3) corrosion of the Fe-tennantite-quartz assemblage by Bi-rich Fe-tennantite (interpreted as fractionated sulfosalt melt).

As mentioned, sulfosalt phase relations and trace element chemistry suggest depositional temperatures above $665{ }^{\circ} \mathrm{C}$ and below $694{ }^{\circ} \mathrm{C}$ (the melting point of the crystalline enargite that precedes $\mathrm{Fe}$-tennantite). Sulfur isotope geothermometry between alunite-enargite pairs at El Indio indicate a depositional temperature of $\sim 700{ }^{\circ} \mathrm{C}$ (Jannas et al. 1999). As the quartz evolved from a metastable silica hydrate, fluid inclusion temperatures are likely to 
be unreliable and TitaniQ estimates from this stage only record minimum temperatures $\left(361-430{ }^{\circ} \mathrm{C}\right)$, as the rocks are not buffered by a Ti-bearing phase (Tanner et al. 2013, 2015).

Paragenesis of 'late pyrite' and Au-stage mineralization: 'Au-stage' veins crosscut enargite-tennantite veins at El Indio; thus, we refer to pyrite from this paragenetic stage as 'late pyrite.' The Au-stage veins host bonanza-grade Au that constituted 'direct shipping' ore. These veins contain quartz, chalcedony and Au, with minor tennantite, pyrite and base metal tellurides (Jannas et al. 1990). Au-stage mineralization was accompanied by pervasive silicification (typically restricted to within $30 \mathrm{~m}$ of veins), with wall rock alteration of sericite-quartz-pyrite and minor pyrophyllite or kaolinite (Jannas et al. 1999). It is likely that the late pyrite formed at higher levels in the deposit in a solfataralike setting (c.f. Henley and Berger 2011b). While secondary fluid inclusion temperatures at El Indio are considered unreliable (Tanner et al. 2015), only fluid inclusion temperature estimates are available for this sample $\left(200-280{ }^{\circ} \mathrm{C}\right.$, Jannas et al. 1999).

\section{Samples}

\section{Sample locations}

A sample suite of 11 samples was kindly provided to us by Francois Robert and the staff of Barrick (Chile), to represent a wide range of sulfosalt assemblages across the mine. A full list of samples is provided in Table 2 of Henley et al. (2012). Of these samples, we chose two samples containing early pyrite (EI 2441 and EI 1285) for more detailed analysis. These samples represent high-temperature feeder zones to the El Indio $\mathrm{Au}-\mathrm{Ag}-\mathrm{Cu}$ high-sulfidation deposit. We also chose a sample containing late Au-stage pyrite (EI 1281) for more detailed analysis. These three samples were chosen because they are linked to previous studies of paragenesis and mineral chemistry (Mavrogenes et al. 2010; Henley et al. 2012; Tanner et al. 2013, 2015). Their location is shown in Fig. 1, and their petrology is described below.

Samples El Indio (EI) 2441 (407185.53E, 6710057.74N; $3925.26 \mathrm{~m} \mathrm{asl}^{3}$ and EI $1285(407065.56 \mathrm{E}, 6709858.6 \mathrm{~N}$; $4116.92 \mathrm{~m}$ asl) were cut from enargite-tennantite ore (containing fractured, massive early pyrite) in a drill core proximal to the Viento Oueste lode- the longest and widest $\mathrm{Cu}$ vein in the deposit (Jannas et al. 1999), in an area which is

\footnotetext{
${ }^{3}$ Grid references for these samples correspond to the coordinate system in Fig. 1 used by Jannas (1995), Jannas et al. (1990, 1999) and Henley et al. (2012).
}

now mined out. We refer to the pyrite in these samples as 'early pyrite.' These pyrite crystals clearly precede sulfosalt deposition as they are crosscut by veinlets of sulfosalt minerals (e.g., Fig. 3d).

Sample EI 1281 (406392.82E, 6709244.91N; 3690.85 m asl) was cut from drill core that intersected silicic alteration surrounding the Indio Sur 3500 lode-the main Au vein in the El Indio deposit hosting bonanza-grade Au mineralization that constituted 'direct shipping ore' (Jannas et al. 1999). As this sample is from the silicic alteration halo associated with the emplacement of Au-stage veins and contains pyrite and quartz, we refer to the pyrite in this sample as 'late pyrite.' Massive early pyrite is strongly brecciated to 5 -to $10-\mathrm{mm}$ clasts infilled by silicic veins containing dispersed sulfosalts and a fresh generation of late pyrite; however, the sample used in this study only contains late pyrite and quartz. Late pyrite was selected for comparative microanalysis relative to the early pyrite in the other samples.

\section{Sample preparation}

Three billets were cut from pristine drill cores of the El Indio veins. The largest pyrite crystals in each billet were cut and mounted in an area $1 \mathrm{~cm}^{2}$ in the center of one polished resin mount, along with the Ruttan pyrite sulfur isotope standard (Whitehouse 2013).

\section{Methodology}

\section{Etching and reflected light microscopy}

Samples were etched in $\mathrm{NaOCl}$ for $90 \mathrm{~s}$, rinsed and then dried with pressurized air. This process tarnishes sulfide minerals and exposes zoning, subgrain boundaries and mineral inclusions under reflected light (e.g., Cox 1987). The etched surfaces were easily removed by light polishing with a $1 / 4 \mu \mathrm{m}$ diamond pad. It should be noted that this process is not completely reproducible. Even with careful timing of the solution's contact with $\mathrm{NaOCl}$, the switch between orange, zoned pyrite (e.g., Fig. 3d) and blue/purple pyrite with white flecks (e.g., Fig. 3c) is very difficult to control. However, in this case the etching was used only to determine discrete chemical zones.

\section{Electron microprobe maps}

Electron microprobe analysis (EMPA) was used to qualitatively map compositional zoning in pyrite. High-resolution maps of $\mathrm{Cu}, \mathrm{Pb}, \mathrm{As}, \mathrm{Ag}$ and back-scattered electron (BSE) imagery were collected using the Cameca 


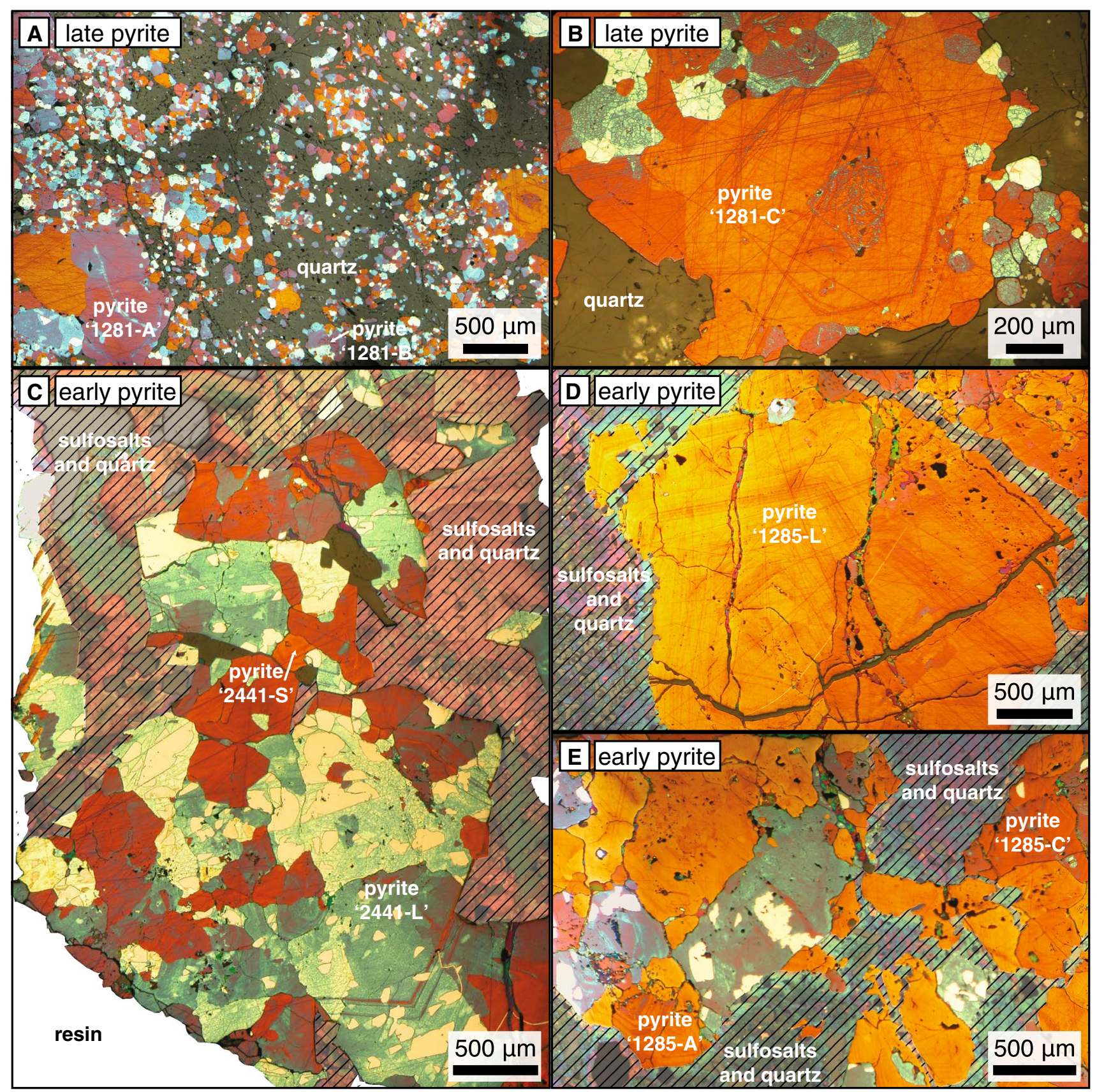

Fig. 3 Textures in El Indio pyrite, revealed by etching with concentrated bleach (reflected light microscopy). Pyrite crystals analyzed in this study are labeled with their respective sample numbers; large regions of sulfosalts, quartz and vugs have been highlighted in white with diagonal lines to avoid confusion with etched pyrite. a, b Sample EI 1281 (late pyrite) shows small euhedral to subhedral pyrite crystals intergrown with quartz. Some vugs (black pits) occur in pyrite crystals, but these are more common in the quartz matrix. c Sample EI 2441 (early pyrite) shows a large zoned crys-

SX100 electron microprobe located at the Research School of Earth Sciences (RSES) at the Australian National University (ANU). $\mathrm{Cu}, \mathrm{Pb}, \mathrm{As}$ and $\mathrm{Ag}$ were collected on separate spectrometers at $15 \mathrm{kV}$ for $>4 \mathrm{~h}$ each. tal (2441-L) with a texture suggestive of subgrain boundaries (in red, white and blue)—oscillatory growth zones in this crystal crosscut subgrains boundaries. Some vugs (black pits), sulfosalt inclusions (green/magenta) and quartz crystals (dark gray) are evident. d, e Sample EI 1285 (early pyrite) shows pyrite crystals contain vugs (black pits) and are fractured by sulfosalt (green/magenta) and quartz veins (dark gray). Sector zones are faintly defined in the large zoned pyrite crystal (1285-L) and subgrain boundaries are apparent in (D)

Elemental concentrations in pyrite were not quantified with EMPA, so maps indicate relative trace element contents. Not all samples analyzed by ion microprobe were mapped using EMPA, due to cost and time constraints. 


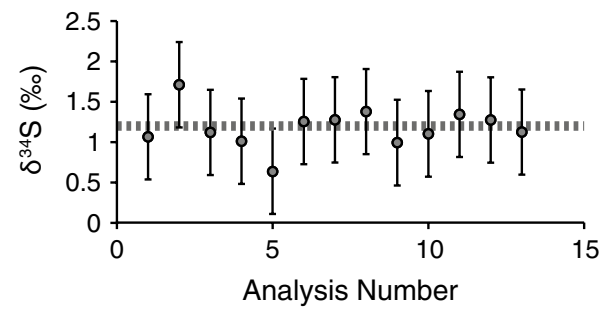

Fig. 4 Reproducibility of the Ruttan pyrite standard throughout the analytical session; $\delta^{34} \mathrm{~S}_{\mathrm{V}-\mathrm{CDT}}=1.2 \%$ (dashed gray line)

\section{Sensitive high-mass resolution ion microprobe for stable isotopes (SHRIMP SI)}

The $\delta^{34} \mathrm{~S}$ composition of El Indio pyrite was measured in situ using the sensitive high-mass-resolution ion microprobe for stable isotopes (SHRIMP SI) located at the RSES, ANU (Ireland et al. 2008). Samples were aluminum-coated before being loaded into the machine. Data were acquired using a cesium primary beam focused to $6 \mathrm{nA}$, using the setup procedure outlined by Holden and Ireland (2011) and Holden et al. (2012). All analyses were collected in the same session, with results normalized to the Ruttan pyrite standard assuming a value of $\delta^{34} \mathrm{~S}_{\mathrm{V}-\mathrm{CDT}}$ of $1.2 \%$ (Whitehouse 2013) (Fig. 4). An internal standard 'NZ pyrite' was used as a secondary standard. The error for each sulfur isotope ratio is reported at the $2 \sigma$ confidence level. Errors assigned to individual analyses are the session-long external reproducibility of the standard ( $2 \sigma$ of the population) added in quadrature to the individual counting statistics. The $2 \sigma$ error of Ruttan pyrite was $0.53 \%$, and the internal precision for unknowns during the session was between 0.020 and $0.154 \%$. SHRIMP SI spots that were not in focus, or overlapped the resin mount, were rejected. The spot size was $\sim 20 \mu \mathrm{m}$. Consecutive spots measured within the same crystal were vertically aligned with the stage, in order to minimize error from beam distortion. In some cases, fine oscillatory zoning prevented isotopic measurement of discrete laminae and resulted in 'mixed values' of consecutive growth zones. The area of SHRIMP SI analyses is shown as a gray stippled line in Figs. 8 and 9.

\section{Laser ablation inductively coupled plasma mass spectrometry (LA-ICP-MS)}

Existing SHRIMP SI spots were analyzed using the 197nm laser ablation inductively coupled plasma mass spectrometer (LA-ICP-MS) located at the RSES, ANU. A spot size of $\sim 37 \mu \mathrm{m}$ diameter was used for each analysis; the outline of each LA-ICP-MS spot is shown as a transparent white circle in Figs. 8 and 9. The laser was turned on for a few pulses to pre-ablate each spot prior to analysis, in order to eliminate surface contamination. This is particularly important because the pyrite surface was tarnished to illuminate zoning. Analyses were run at a repetition rate of $10 \mathrm{~Hz}$ with $100 \%$ mirror, keeping the gas signal at $\sim 30 \mathrm{~mJ}$ with the LA-ICP-MS system tuned to low oxide production rates (typically $\mathrm{ThO}^{+} / \mathrm{Th}^{+}<0.4 \%$ ). Pyrite crystals were ablated for $\sim 40 \mathrm{~s}$; however, only the first $25 \mathrm{~s}$ or less of signal was selected for data reduction, in order to reduce down-hole fractionation effects.

The data were reduced using iolite (Paton et al. 2011), normalized to $46.55 \mathrm{wt} \% \mathrm{Fe}$. We assumed stoichiometry as no variation in $\mathrm{Fe}$ was observed in time-resolved analyses and typically the minor elements combined were $<1 \mathrm{wt} \%$. During data reduction, data spikes resulting from unavoidable ablation of mineral and melt inclusions were selectively removed. However, some analyses drilled through fine oscillatory growth zones that could not be selectively removed (their occurrence is noted in Supplementary Table 1). So rather than the present error for trace element analyses, we present two standard deviations ( $2 \sigma)$ from the range of data selected for analysis - in order to demonstrate the extent of oscillatory zoning.

Analyses of El Indio pyrite were calibrated using NIST610 glass and the sulfide standards MASS-1 and 'Canmet' Po727. Au was calibrated to Canmet Po727; $\mathrm{Cr}, \mathrm{Mn}, \mathrm{Co}, \mathrm{Ni}, \mathrm{Cu}, \mathrm{Zn}, \mathrm{Ge}$ and $\mathrm{Sb}$ were calibrated to the $\mathrm{Fe}-\mathrm{Cu}-\mathrm{Zn}$ sulfide MASS-1; and the remaining elements were reduced to NIST610 (see Supplementary Table 2 for preferred values and a list of the masses analyzed). The contents of trace elements in each mineral and the limits of detection (LOD) were calculated using the methods described in Longerich et al. (1996).

\section{Results}

\section{Morphology and zoning}

Early pyrite Etching revealed that the fractured early, massive pyrite grains in samples EI 2441 and EI 1285 contain a matrix of subhedral to anhedral pyrite crystals with idiomorphic oscillatory zonation, up to $5 \mathrm{~mm}$ in diameter. Subgrain boundaries were evident in both samples, distinguished by white-, red- and blue-colored regions (Fig. 3ce). Crosscutting sulfosalt dikelets and quartz veins do not disturb idiomorphic growth bands (Fig. 3d), so there is no evidence for post-depositional modification of trace elements due to diffusive processes.

Of the elements mapped in early pyrite using EMPA, $\mathrm{Cu}$ is the only element to show compositional variation (As, $\mathrm{Zn}$ and $\mathrm{Ag}$ are below detection). The fine oscillatory $\mathrm{Cu}$ banding occurs from core to rim of each crystal and correlates with the zonation observed in etched samples. EMPA 
images the structure of crystals in greater detail than etching, recording finer oscillatory zones and decayed growth bands. Regions of pyrite dissolution are associated with $\mathrm{Cu}$-rich zones where no distinct layering is evident and abundant vugs and mineral inclusions are present (e.g., Fig. 5d). EMPA also revealed microscale vugs and inclusions aligned along specific growth bands in both early, massive pyrite and silicic alteration pyrite (Fig. 5a, e). Figure 5d, e shows multiple changes in crystal habit across core-to-rim transects in early pyrite.

Late pyrite Pyrite crystals in sample EI 1281 are much smaller than the massive early pyrite crystals. They are typically $\sim 200 \mu \mathrm{m}$, with some crystals up to $1 \mathrm{~mm}$ across (Table 2). The late pyrite crystals do not contain consistent oscillatory zoning from core to rim. Instead, they exhibit regions of fine growth bands with homogenous zones in between (Fig. 5). These crystals are euhedral to subhedral and contain small vugs and mineral inclusions, present as continuous layers mantling distinct growth bands. EMPA maps show that $\mathrm{As}$ and $\mathrm{Pb}$ are enriched in the earliest euhedral growth zones (Ag is below detection). $\mathrm{Cu}$ is also above detection in EMPA and occurs as fine colloform bands on the outermost regions of crystals. The $\mathrm{Cu}$-rich colloform bands identified by EMPA correspond to fine bands of vugs visible under reflected light (Figs. 3b, 5c).

\section{In situ sulfur isotope analysis of pyrite}

The complete isotopic dataset $(n=99)$ is provided in Supplementary Table 1 and shown in Figs. 6 and 7. The measured intracrystalline $\delta^{34} \mathrm{~S}$ variation exceeds analytical error in each crystal except 1281-B $(n=4)$. These data separate into two populations corresponding to paragenetic stage. Figure 6 shows that late pyrite is distinctly enriched in $\delta^{34} \mathrm{~S}$ $(0.05$ to $4.77 \% o, \pm 0.5 \%$ ) relative to early pyrite $(-3.19$ to $1.88 \% o, \pm 0.5 \%$ o); the variability between crystals is shown in Fig. 7. Late pyrite crystal 1281-C exhibited the greatest intracrystalline range of $\delta^{34} \mathrm{~S}$ at $4.48 \%$; an intracrystalline range of up to $3.31 \%$ was recorded in early pyrite.

\section{In situ trace element analysis of pyrite}

In situ analyses were used to collect data for 19 trace elements in pyrite $(n=129)$. Of these elements, $\mathrm{Co}, \mathrm{Ni}, \mathrm{Cu}$, $\mathrm{Zn}, \mathrm{As}, \mathrm{Se}, \mathrm{Ag}, \mathrm{Sb}, \mathrm{Te}, \mathrm{Au}, \mathrm{Pb}, \mathrm{Bi}$ and $\mathrm{Mn}$ showed meaningful variations, while $\mathrm{Sc}, \mathrm{Cr}, \mathrm{V}, \mathrm{Mo}, \mathrm{Ge}$ and $\mathrm{Sn}$ were consistently at or below detection. These data and their respective limits of detection are presented in Table 1 or are available as a spreadsheet (Supplementary Table 1).

While numerous methods were employed to reduce contamination, the abundance of microscale vugs in El Indio pyrite (which accumulate material from the polishing pad) resulted in minor contamination in 9 of the 129 analyses (evidenced by abnormal levels of $\mathrm{Al}$ and/or $\mathrm{Mg}$ ). We include these data in Figs. 8 and 9, as most elements are not affected by contamination (but are clearly labeled in Supplementary Table 1). Supplementary Table 1 also identifies 18 analyses that suffer from the nugget effect (analyses where abundant spikes in $\mathrm{Au}$ or Bi cannot be removed from LA-ICP-MS spectra).

The trace element results indicate that all the elements analyzed are distributed heterogeneously throughout each pyrite crystal, enriched within discrete growth zones. Early pyrite contains significant $\mathrm{Cu}$ with trace $\mathrm{As}, \mathrm{Co}, \mathrm{Se}, \mathrm{Bi}, \mathrm{Ni}$, $\mathrm{Pb}, \mathrm{Sb}, \mathrm{Ge}, \mathrm{Ag}, \mathrm{Zn}, \mathrm{Te}$ and $\mathrm{Au}$. Late pyrite contains significant As with minor $\mathrm{Zn}$ and $\mathrm{Cu}$ and trace $\mathrm{Pb}, \mathrm{Mn}, \mathrm{Se}, \mathrm{Ni}$, $\mathrm{Co}, \mathrm{Sb}, \mathrm{Ge}, \mathrm{Te}, \mathrm{Bi}, \mathrm{Ag}$ and $\mathrm{Sn}$. A summary of this information is provided in Table 2 .

The mean trace element abundances (Table 1) show that $\mathrm{Cu}$, Se and $\mathrm{Bi}$ are most concentrated in early pyrite, while $\mathrm{Zn}, \mathrm{Mn}, \mathrm{Pb}, \mathrm{As}, \mathrm{Sc}, \mathrm{V}$ and Mo are most concentrated in late pyrite. $\mathrm{Ag}, \mathrm{Ge}, \mathrm{Sn}$ and $\mathrm{Ta}$ are more evenly distributed between samples. The mean and range of data (Table 1; Fig. 7) show that early pyrite sample EI 1285 has the highest $\mathrm{Au}$ and Se contents, while early pyrite EI 2441 has the highest $\mathrm{Co}$, $\mathrm{Ni}$ and $\mathrm{Cr}$ contents.

Coupling of trace elements within crystals $\mathrm{Co}$ and $\mathrm{Ni}$ are the only elements that consistently co-vary between growth zones within individual pyrite crystals (Figs. 8, 9). Cu exhibits distinct zonation in EMPA maps of 'massive pyrite,' but the trace element dataset shows that $\mathrm{Cu}$ zonation is not routinely accompanied by variations in any other element. Many trace elements co-vary between discrete growth bands, but do not consistently vary across the width of the crystal. For example, $\mathrm{Cu}$ is strongly coupled with $\mathrm{Au}, \mathrm{Sb}, \mathrm{Pb}, \mathrm{Sn}$ and $\mathrm{Ag}$ in the core of late pyrite sample EI 1281-C, but not in the outer growth rims (Fig. 8). $\mathrm{Bi}, \mathrm{Pb}, \mathrm{Ag}$ and $\mathrm{Au}$ co-vary in some growth zones of both EI 2441-L and EI 1285-L, but not consistently across the width of either crystal.

Chronological analysis of geochemical data versus bulk $X-Y$ plots Fig. 10 shows a positive correlation between As and $\delta^{34} \mathrm{~S}$ and a negative correlation between $\mathrm{Cu}, \mathrm{Se}$ and $\delta^{34} \mathrm{~S}$ when plotted in bulk. However, these correlations are not replicated when the same data are visualized in situ in the context of crystal zonation (Figs. 8, 9). That is, when the geochemical data were plotted against relative time (i.e., from crystal core to), $\mathrm{As}, \mathrm{Cu}$ and $\mathrm{Se}$ do not co-vary with $\delta^{34} \mathrm{~S}$, so we do not consider the apparent relationships between $\mathrm{As}, \mathrm{Cu}, \mathrm{Se}$ and $\delta^{34} \mathrm{~S}$ on a bulk $\mathrm{X}-\mathrm{Y}$ plot to be meaningful.

\section{Discussion}

Textural and chemical zonation in vein minerals preserves evidence of changes in the states of saturation of phases as 

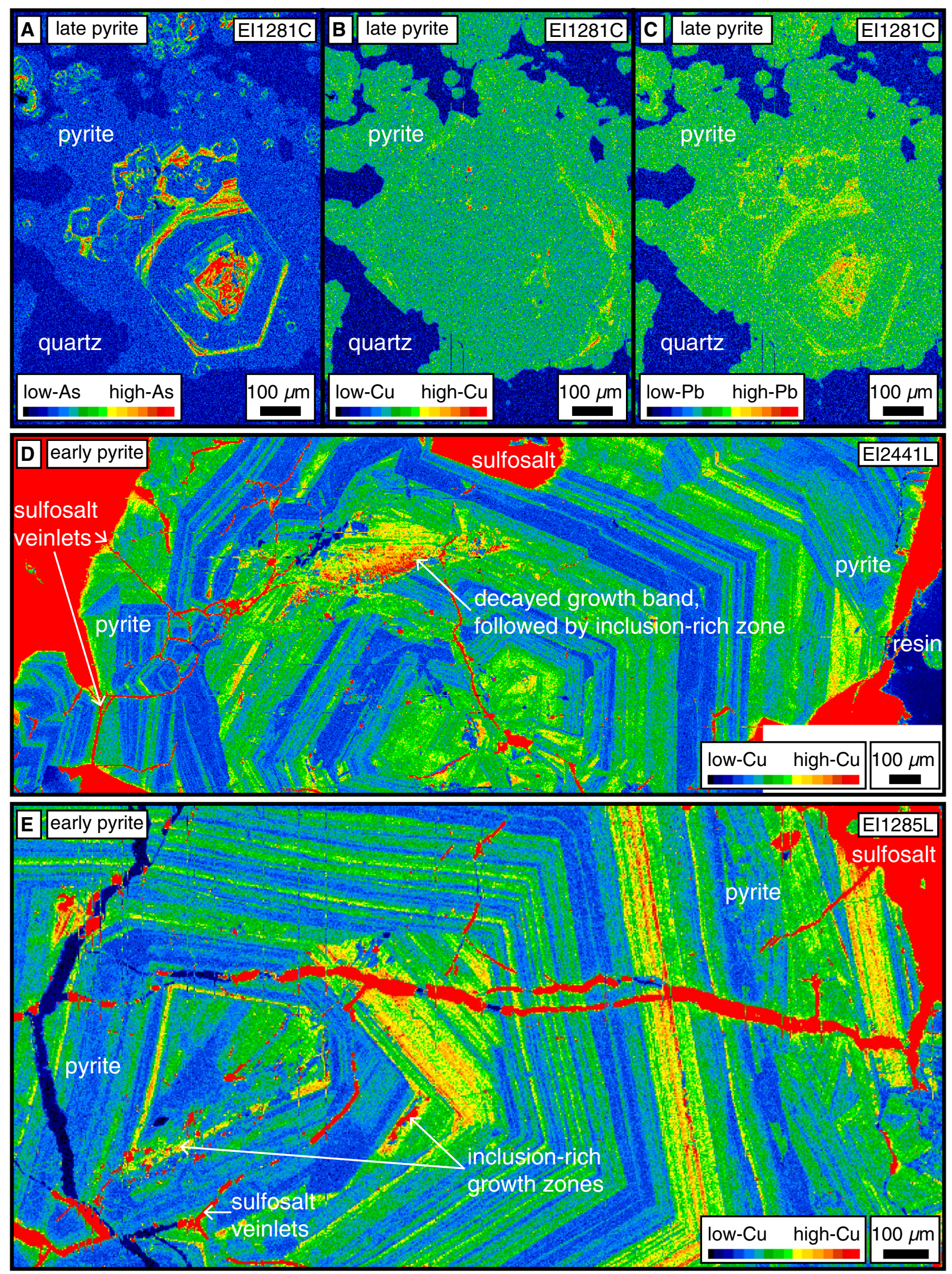
4 Fig. 5 Electron microprobe maps of trace element variation in pyrite. a As variation in late pyrite (EI 1281, crystal C); b Cu variation in late pyrite (EI 1281, crystal C); c Pb variation in late pyrite (EI 1281, crystal C); d Cu variation in early pyrite (EI 2441, crystal L); e Cu variation in early pyrite (EI 1285, crystal L)

the physicochemical environment changes through time. Here, we compare the geochemistry between two generations of zoned pyrite crystals at El Indio: early pyrite from

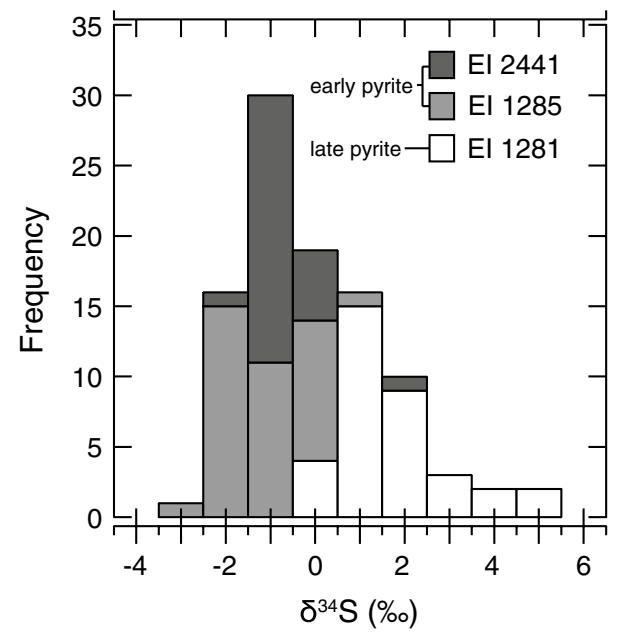

Fig. 6 Frequency histogram of in situ sulfur isotope analyses in El Indio pyrite $(n=99)$. This plot demonstrates that the late pyrite (white) is systematically heavier than early pyrite samples (medium and dark gray) high-temperature feeder zones and late pyrite accompanied by pervasive silicification, in order to better understand physicochemical differences between the two depositional environments.

The microanalytical data provided in this paper show that the early pyrite preceding sulfosalt deposition is chemically distinct from late pyrite (Table 2). Late pyrite is isotopically distinct from early pyrite, as it is more enriched in ${ }^{34} \mathrm{~S}$ (Fig. 6). $\mathrm{Cu}$ is concentrated in early pyrite, while As is concentrated in late pyrite (Figs. 8 and 9). Despite these clear distinctions, there is no systematic co-variation of either trace elements, or trace elements and isotopes in early and late pyrite, unlike other in situ studies of coupled $\delta^{34} \mathrm{~S}$ and trace element analysis in pyrite from the West Banshee, Turquoise Ridge, Porgera and Wallaby Au deposits (Barker et al. 2009; Peterson and Mavrogenes 2014; Murray 2011). These pyrite studies show a clear relationship between $\delta^{34} \mathrm{~S}$ and trace element content, which they use to infer changes in fluid chemistry during deposition, triggered by changes in oxidation state, pressure, temperature and/or $\mathrm{pH}$. However, such variables cannot account for the systematic decoupling of trace elements with $\delta^{34} \mathrm{~S}$ within El Indio pyrite or the poor co-variation between trace element pairs (Figs. 8, 9) at El Indio. In the following discussion, we explore the controls on $\delta^{34} \mathrm{~S}$ and trace element variation in El Indio pyrite, in order to explain the decoupling between sulfur isotopes and trace elements as well as to elucidate changes in physicochemical conditions within the deposit.
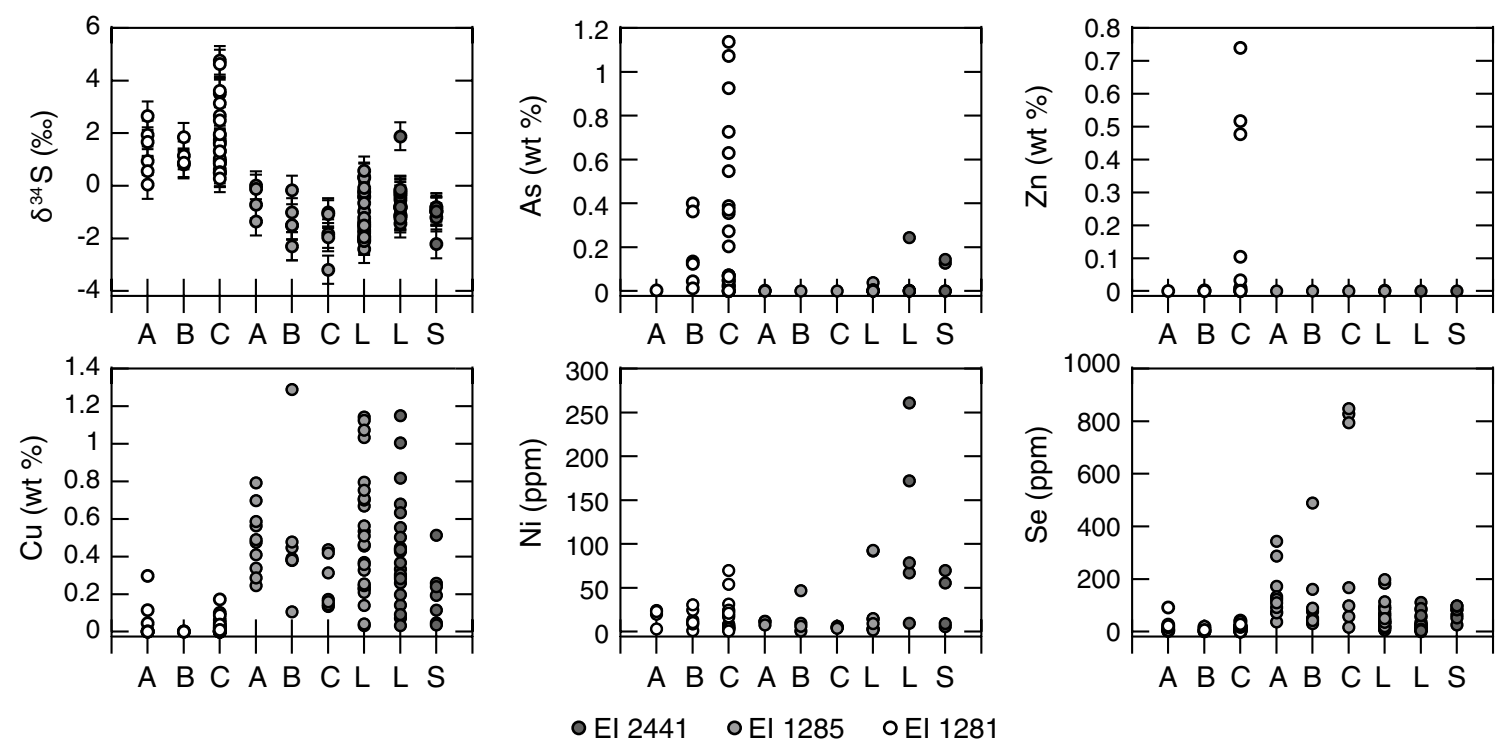

A B C A B C L L S

Fig. 7 Plots showing variation of $\delta^{34} \mathrm{~S}$ and trace element abundance between El Indio pyrite crystals. Letters along the $x$-axis correspond to the names of individual pyrite crystals within each sample, as shown in Figs. 3, 5 and Supplementary Table 1. Early pyrite (EI 2441 and EI 1285) is shown in medium and dark gray, while late pyrite (EI 1281) is shown in white 
Table 1 Sulfur isotope and trace element data of El Indio pyrite

\begin{tabular}{|c|c|c|c|c|c|c|c|}
\hline & \multicolumn{4}{|c|}{ Early pyrite } & \multirow{2}{*}{\multicolumn{2}{|c|}{$\frac{\text { Late pyrite }}{\text { Sample EI } 1281}$}} & \multirow{3}{*}{ Mean LOD } \\
\hline & \multicolumn{2}{|c|}{ Sample EI 2441} & \multicolumn{2}{|c|}{ Sample EI 1285} & & & \\
\hline & Mean & Range & Mean & Range & Mean & Range & \\
\hline$\delta^{34} S(\% o)$ & -0.76 & -2.21 to 1.88 & -1.17 & -3.19 to 0.58 & 1.61 & 0.05 to 4.77 & n.a. \\
\hline${ }^{45} \mathrm{Sc}(\mathrm{ppm})$ & $b d l$ & & 0.05 & $0.05-0.05$ & 0.7 & $0.1-2$ & 0.054 \\
\hline${ }^{51} \mathrm{~V}(\mathrm{ppm})$ & 0.1 & $0.05-0.1$ & 0.04 & $0.01-0.3$ & 0.5 & $0.02-12$ & 0.011 \\
\hline${ }^{52} \mathrm{Cr}(\mathrm{ppm})$ & 0.2 & $0.2-0.2$ & 0.4 & $0.2-3$ & 0.4 & $0.2-0.7$ & 0.189 \\
\hline${ }^{55} \mathrm{Mn}$ (ppm) & 0.4 & $0.05-5$ & 0.3 & $0.1-4$ & 33 & $0.1-850$ & 0.057 \\
\hline${ }^{59} \mathrm{Co}(\mathrm{ppm})$ & 224 & $0.004-1277$ & 5 & $0.004-44$ & 10 & $0.1-41$ & 0.006 \\
\hline${ }^{61} \mathrm{Ni}(\mathrm{ppm})$ & 81 & $6-261$ & 18 & $1-93$ & 16 & $1-70$ & 1.087 \\
\hline${ }^{65} \mathrm{Cu}(\mathrm{ppm})$ & 3774 & $324-11,500$ & 4718 & $332-12,900$ & 244 & $0.5-2970$ & 0.245 \\
\hline${ }^{66} \mathrm{Zn}(\mathrm{ppm})$ & 2 & $0.3-10$ & 3 & $0.2-28$ & 907 & $0.3-7400$ & 0.310 \\
\hline${ }^{72} \mathrm{Ge}(\mathrm{ppm})$ & 6 & $6-7$ & 6 & $5-6$ & 6 & $5-9$ & 0.180 \\
\hline${ }^{73} \mathrm{Ge}(\mathrm{ppm})$ & 0.9 & $0.7-1$ & 0.7 & $0.5-1$ & 1 & $0.5-10$ & 0.168 \\
\hline${ }^{75}$ As (ppm) & 233 & $1-2450$ & 18 & $0.7-385$ & 2292 & $0.9-11,370$ & 0.640 \\
\hline${ }^{77} \mathrm{Se}$ (ppm) & 39 & $1-111$ & 136 & $7-848$ & 15 & $0.7-93$ & 0.694 \\
\hline${ }^{82} \mathrm{Se}(\mathrm{ppm})$ & 41 & $1-109$ & 137 & $6-860$ & 16 & $0.7-100$ & 0.654 \\
\hline${ }^{95} \mathrm{Mo}$ (ppm) & $b d l$ & & $b d l$ & & 0.2 & $0.04-0.6$ & 0.022 \\
\hline${ }^{107} \mathrm{Ag}(\mathrm{ppm})$ & 5 & $0.1-25$ & 5 & $0.1-123$ & 4 & $0.04-42$ & 0.049 \\
\hline${ }^{118} \mathrm{Sn}(\mathrm{ppm})$ & 1 & $0.1-5$ & 0.7 & $0.2-2$ & 1 & $0.2-4$ & 0.167 \\
\hline${ }^{121} \mathrm{Sb}(\mathrm{ppm})$ & 13 & $0.1-181$ & 1 & $0.1-14$ & 10 & $0.1-108$ & 0.064 \\
\hline${ }^{125} \mathrm{Te}(\mathrm{ppm})$ & 3 & $0.3-22$ & 1 & $0.2-5$ & 5 & $0.2-17$ & 0.271 \\
\hline${ }^{181} \mathrm{Ta}(\mathrm{ppm})$ & $b d l$ & & 0.1 & $0.1-0.1$ & 0.2 & $0.004-0.4$ & 0.002 \\
\hline${ }^{197} \mathrm{Au}(\mathrm{ppm})$ & 0.3 & $0.004-2$ & 2 & $0.006-82$ & 0.7 & $0.003-5$ & 0.002 \\
\hline${ }^{208} \mathrm{~Pb}(\mathrm{ppm})$ & 12 & $0.03-80$ & 6 & $0.02-103$ & 71 & $0.02-1049$ & 0.017 \\
\hline${ }^{209} \mathrm{Bi}(\mathrm{ppm})$ & 36 & $0.04-173$ & 115 & $0.1-5000$ & 4 & $0.03-64$ & 0.022 \\
\hline
\end{tabular}

Trace element values $>1 \mathrm{ppm}$ are given to the nearest integer. $L O D$ limit of detection, $b d l$ below detection limit, n.a. not applicable

\section{Previous $\delta^{34} \mathrm{~S}$ isotope studies of pyrite at EI Indio and other high-sulfidation deposits}

Pyrite at El Indio formed from the reduction of $\mathrm{SO}_{2} \rightarrow \mathrm{H}_{2} \mathrm{~S} \rightarrow \mathrm{FeS}_{2}$ (as pyrite $\left(\mathrm{FeS}_{2}\right.$ ) contains $\mathrm{S}^{2-}$ rather than $\mathrm{S}^{4+}$ ). Figure 11 shows that the range of $\delta^{34} \mathrm{~S}$ in El Indio pyrite from this study is slightly heavier than the six bulk analyses of early and late pyrite measured by Jannas et al. (1990). However, it is worth noting that the intracrystalline range of $\delta^{34} \mathrm{~S}(4.48 \%$ ) from one crystal in this study exceeds the range of data measured by Jannas et al. (1990). Figure 10 shows that the range of $\delta^{34} S_{\text {pyrite }}$ from this study is well within the range of bulk $\delta^{34} S_{\text {pyrite }}$ measured from other intermediate-sulfidation and high-sulfidation deposits. One of the difficulties in interpreting the data for this study is the lack of other intracrystalline $\delta^{34} \mathrm{~S}_{\text {pyrite }}$ analyses from other intermediate-sulfidation and high-sulfidation deposits. If intracrystalline $\delta^{34} S_{\text {pyrite }}$ analyses were available for the other deposits in Fig. 10, it is likely that the $\delta^{34} \mathrm{~S}_{\text {pyrite }}$ range for each deposit would be expanded and reveal greater complexity in physicochemical processes operating during deposition.

\section{Estimates of the range of $\delta^{34} \mathrm{~S}_{\text {fluid }}$ at EI Indio}

Analyses of $\delta^{18} \mathrm{O}$ and $\delta \mathrm{D}$ from alunite at Tambo $(\sim 5 \mathrm{~km}$ south of El Indio) and Pascua-Lama ( $\sim 50 \mathrm{~km}$ north of El Indio) show that the mineralizing fluids in this region were dominantly magmatic, with little evidence of meteoric mixing (Deyell et al. 2004, 2005a, b). Deyell et al. (2004, $2005 \mathrm{a}, \mathrm{b})$ attribute the strong magmatic isotopic signature to a local arid climate and limited availability of meteoric water. As these deposits are shallow, they would be more susceptible to influx of meteoric water than the deeper samples in this study, from 650 to $1150 \mathrm{~m}$ below the paleosurface (Henley et al. 2012). Thus, it is reasonable to assume that the El Indio samples in this study also formed from a dominantly magmatic fluid.

Estimates for the $\delta^{18} \mathrm{O}$ of primary magmatic water are derived from the 'normal' isotopic range for magmatic rocks in equilibrium with $\mathrm{H}_{2} \mathrm{O}>700{ }^{\circ} \mathrm{C}$ (Taylor 1979). 

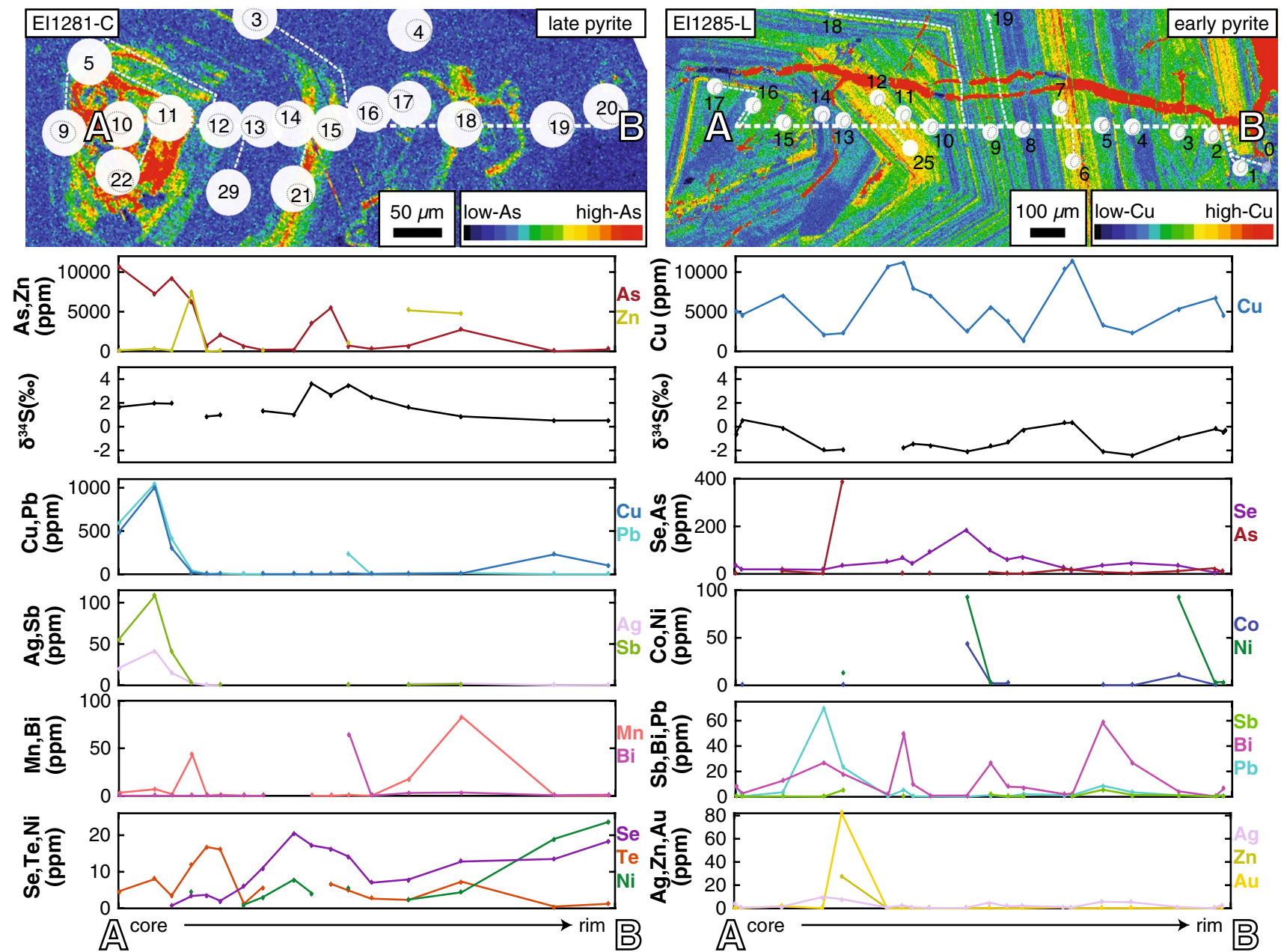

Fig. 8 Transect showing $\delta^{34} \mathrm{~S}$ and trace element variation from core to rim in late pyrite EI 1281-C (left hand side) and early pyrite EI 1285-L (right hand side). LA-ICP-MS analyses are shown as white

However, estimating the range $\delta^{34} \mathrm{~S}$ is much more difficult, given varying degrees of sediment assimilation in upper crustal magmas and the range and complexity of sulfur speciation in subvolcanic environments. Henley et al. (2015) have recently shown that the reaction of plagioclase with $\mathrm{SO}_{2}$ (gas) produces anhydrite and triggers rapid disproportionation of $\mathrm{SO}_{2}$ to sulfate and reduced $\mathrm{S}$ in porphyry-Cu environments, which could produce additional isotopic fractionation at the source, prior to fluid ascent.

In order to overcome the difficulties in estimating the $\delta^{34} \mathrm{~S}$ of primary magmatic water and account for the range of reactions between sulfur species during fluid ascent, we use estimates of $\delta^{34} S_{\text {fluid }}$ measured from high-temperature fumaroles on arc volcanoes $\left(\delta^{34} \mathrm{~S}_{\text {fluid }}=0-10 \%\right.$; Oppenheimer et al. 2011). We consider these values appropriate estimates of the parental fluid at El Indio, given the limited evidence for incursion of meteoric water (Deyell et al. 2004, 2005a, b). The proportion of $\mathrm{H}_{2} \mathrm{~S}: \mathrm{SO}_{2}$ in active fumaroles circles, with corresponding SHRIMP analyses shown as broken gray ellipses. Zonation is shown using EMPA maps. All trace elements above detection are plotted

$\left(0-41 \% \mathrm{H}_{2} \mathrm{~S}\right.$; Oppenheimer et al. 2011) is roughly commensurate with the proportion of $\mathrm{H}_{2} \mathrm{~S}: \mathrm{SO}_{2}$ measured from fluid inclusions in 'magmatic steam' alunite $\left(0-58 \% \mathrm{H}_{2} \mathrm{~S}\right.$; Landis and Rye 2005). We do not have a method for estimating the $\mathrm{H}_{2} \mathrm{~S}: \mathrm{SO}_{2}$ of parental fluids in the samples studied here, but we know that the bulk $\delta^{34} \mathrm{~S}$ of parental fluids at El Indio is still likely to be limited to the range of $10 \%$ o observed in natural high-temperature fumaroles (Oppenheimer et al. 2011).

\section{Calculating the $\delta^{34} \mathrm{~S}$ of early pyrite at EI Indio}

To assess the processes controlling $\delta^{34} \mathrm{~S}$ fractionation in early pyrite, we calculated the range of $\delta^{34} \mathrm{~S}$ expected from equilibrium fractionation of pyrite from a one-phase magmatic vapor at $670{ }^{\circ} \mathrm{C}$ (the temperature of EI 2441 and EI 1285 assemblages from sulfosalt phase relations, Henley et al. 2012). A range of $\mathrm{SO}_{2}$-rich parent fluids from 0 to 

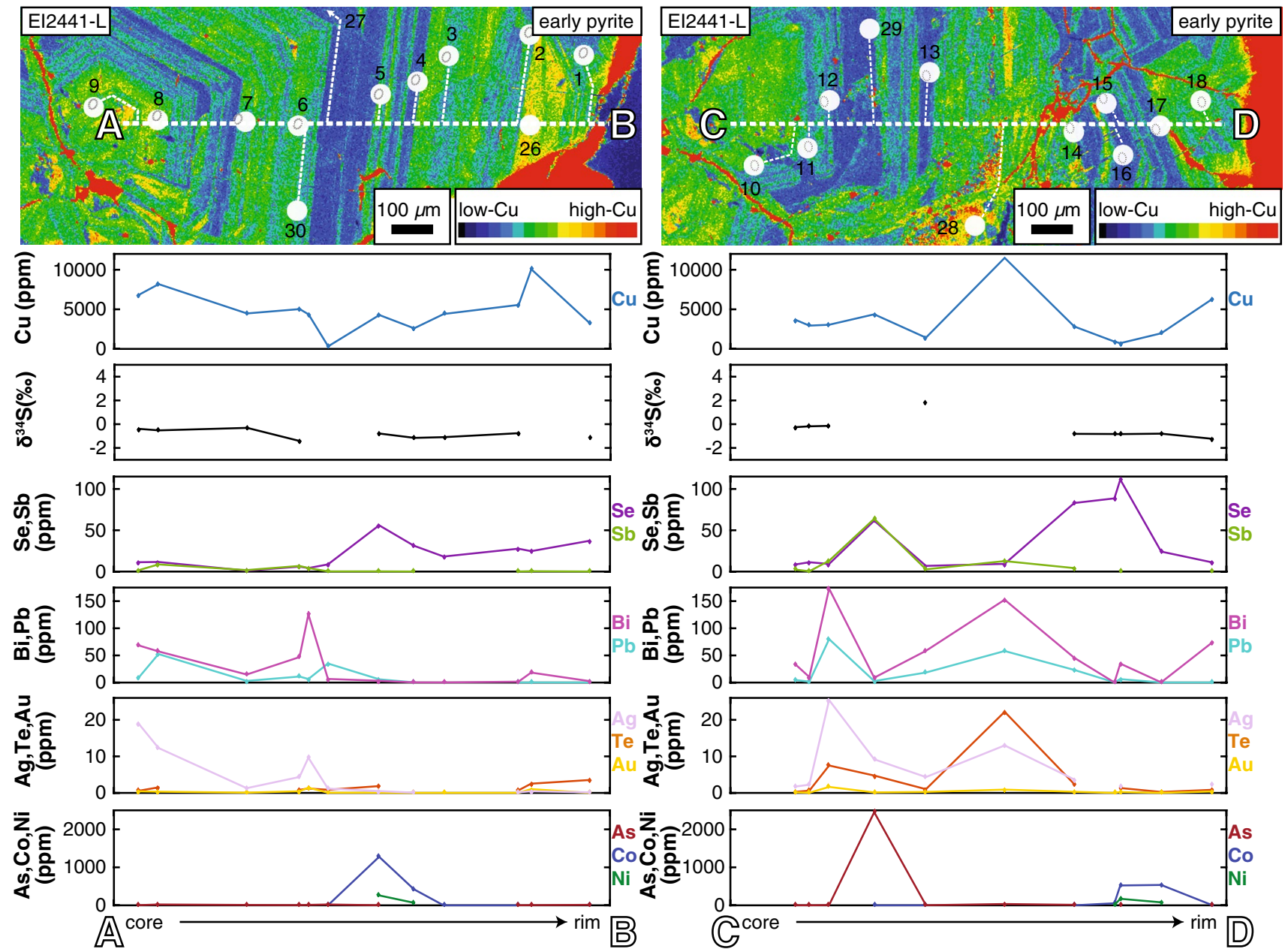

Fig. 9 Two core-to-rim transects showing $\delta^{34} \mathrm{~S}$ and trace element variation across early pyrite crystal EI 2441-L. LA-ICP-MS analyses are shown as white circles, with corresponding SHRIMP analyses shown as broken gray ellipses. Zonation is shown using EMPA maps.

All trace elements above detection are plotted. Note that the sampling scale is not sufficient to resolve coherent geochemical trends between the two transects

Table 2 Summary comparison between early pyrite and late pyrite

\begin{tabular}{|c|c|c|}
\hline & Early pyrite & Late pyrite \\
\hline Assemblage & Pyrite crosscut by sulfosalts and quartz & $\begin{array}{l}\text { Pyrite intergrown with small subeuhedral quartz } \\
\text { crystals }(<1 \mathrm{~mm})\end{array}$ \\
\hline Crystal size & Typically $>500 \mu \mathrm{m}$, up to $5 \mathrm{~mm}$ diameter & Typically $\sim 200 \mu \mathrm{m}$, up to $1 \mathrm{~mm}$ diameter \\
\hline Morphology/texture in etched crystals & $\begin{array}{l}\text { Massive texture with large and small crystals } \\
\text { intergrown. Crystals exhibit very fine } \\
\text { idiomorphic oscillatory banding }\end{array}$ & $\begin{array}{l}\text { Small euhedral crystals that exhibit idiomorphic } \\
\text { oscillatory banding, with colloform bands of vugs }\end{array}$ \\
\hline Isotopic signature & $\delta^{34} \mathrm{~S}_{\text {pyrite }}=-3.19$ to $1.88 \%$ & $\delta^{34} S_{\text {pyrite }}=0.05$ to $4.77 \%$ \\
\hline Minor elements $>1 \mathrm{wt} \%$ & $\mathrm{Cu}$ & As \\
\hline Trace elements $>1000 \mathrm{ppm}$ & $\mathrm{Co}, \mathrm{As}, \mathrm{Bi}$ & $\mathrm{Cu}, \mathrm{Zn}, \mathrm{Pb}$ \\
\hline Trace elements $10-1000 \mathrm{ppm}$ & $\mathrm{Ni}, \mathrm{Zn}, \mathrm{Se}, \mathrm{Ag}, \mathrm{Sb}, \mathrm{Te}, \mathrm{Au}, \mathrm{Pb}, \mathrm{Bi}$ & V, Mn, Co, Ni, Ge, Se, Ag, Sb, Te, Pb, Bi \\
\hline
\end{tabular}

$10 \%$ (Oppenheimer et al. 2011) at $670{ }^{\circ} \mathrm{C}$ (Henley et al. 2012 ) would produce a range of $\mathrm{H}_{2} \mathrm{~S}$ gas from -4.8 to $5.2 \%$, which would in turn produce pyrite with a range from -4.4 to $5.6 \%$ (using fractionation factors from Ohmoto and Rye 1979). Thus, the measured values for early pyrite at El Indio ( -3.19 to $1.88 \%$ ) are commensurate 

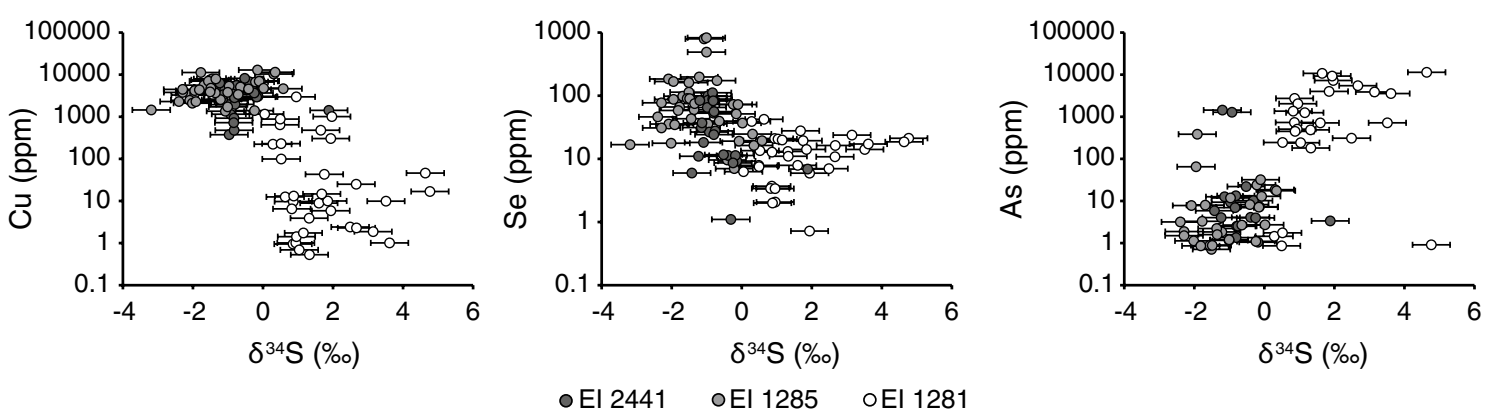

Fig. 10 Plots of the $\mathrm{Cu}, \mathrm{Se}$ and As content of El Indio pyrites against $\delta^{34}$ S. Early pyrite (EI 2441 and EI 1285) is shown in dark and medium gray, while late pyrite (EI 1281) is shown in white. These are the only elements to show a weak correlation with $\delta^{34} \mathrm{~S}$ when the dataset is merged. While these are convincing trends, when the geo-

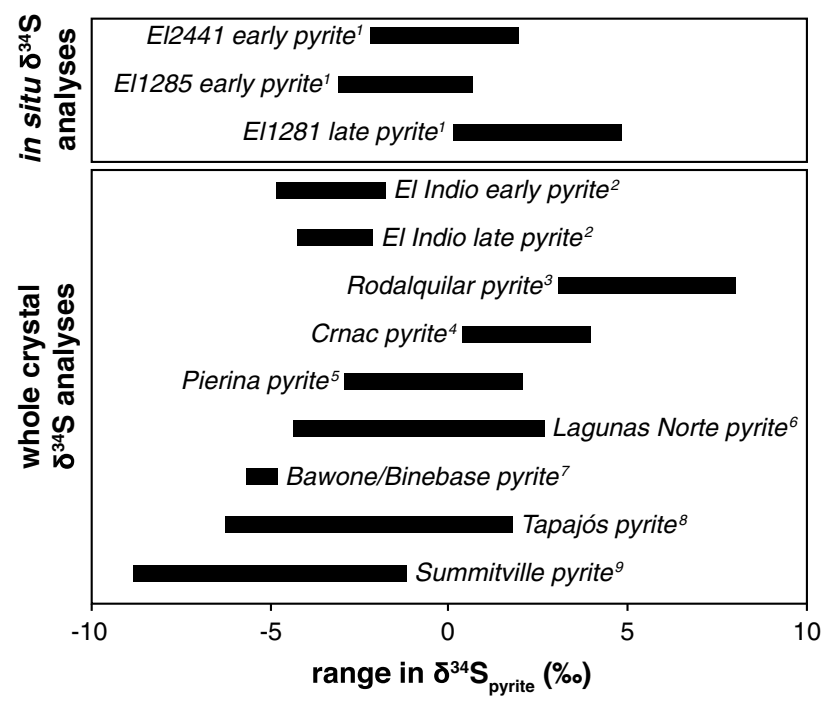

Fig. 11 Range of $\delta^{34} \mathrm{~S}$ in pyrite crystals from high-/intermediatesulfidation deposits. Sources (1) this study; (2) Jannas et al. 1990; (3) Arribas et al. 1995; (4) Borojević Šoštarić et al. 2011; (5) Fifarek and Rye 2005; (6) Cerpa et al. 2013; (7) King et al. 2014; (8) Juliani et al. 2005; (9) Bethke et al. 2005

with and most easily explained by equilibrium fractionation during sublimation from ascending magmatic vapor with a $\sim 5 \%$ change in the $\delta^{34} \mathrm{~S}$ of the parental fluid during crystal growth. This observation suggests that early pyrite in high-temperature feeder zones at El Indio precipitated directly from $\mathrm{H}_{2} \mathrm{~S}$ produced by ascending $\mathrm{SO}_{2}$-rich magmatic vapor.

\section{Calculating the of $\delta^{34} \mathrm{~S}$ of late pyrite at El Indio}

The difficulty in calculating the $\delta^{34} \mathrm{~S}$ of late pyrite is that no independent temperature estimates are available and fluid inclusions from El Indio quartz crystals are considered unreliable (Tanner et al. 2015). It is probable that the chemical data are plotted against relative time (from crystal zonation in Figs. 8, 9), As, $\mathrm{Cu}$ and Se do not co-vary with $\delta^{34} \mathrm{~S}$, so we do not consider the apparent relationships between $\mathrm{As}, \mathrm{Cu}$, Se and $\delta^{34} \mathrm{~S}$ in this figure to be meaningful

late pyrite from this study formed at higher levels in the deposit in a solfatara-like, epithermal setting (c.f. Henley and Berger 2011b), unlike early pyrite which is restricted to the high-temperature feeder zones. Therefore, depositional temperatures for late pyrite are likely to be lower than in early pyrite, suggesting deposition of late pyrite from a liquid phase (a condensate) rather than directly from magmatic vapor. As previously discussed, we consider the input of meteoric water to be negligible in these samples due to the arid climate (Deyell et al. 2004, 2005a, b). As the fluid is a liquid rather than a gas, variations in $\delta^{34} \mathrm{~S}$ may be caused by changes in $\mathrm{fO}_{2}$, fluid mixing, $\mathrm{pH}$, and sulfur disproportionation. As no other temperature estimates are available for this sample, we have had to rely on the secondary fluid inclusions measured by Jannas et al. (1999) as minimum temperature estimates to evaluate the sulfur isotope data.

Assuming equilibrium fractionation from a range of $\mathrm{SO}_{2}$-rich parent fluids from 0 to $10 \%$ (Oppenheimer et al. 2011) between 200 and $280{ }^{\circ} \mathrm{C}$ (from fluid inclusion data, Jannas et al. 1999), the product $\mathrm{H}_{2} \mathrm{~S}$ gas would range in $\delta^{34} \mathrm{~S}$ from -20.5 to $-4.9 \%$, which would in turn produce pyrite with a range of $\delta^{34} \mathrm{~S}$ from -22.3 to $-6.2 \%$ o (using fractionation factors from Ohmoto and Rye 1979). The values for the $\delta^{34} \mathrm{~S}$ of late pyrite at El Indio $(-0.05$ to $4.77 \%$ ) are much more enriched in ${ }^{34} \mathrm{~S}$; thus, they cannot only be explained by simple changes in the $\delta^{34} \mathrm{~S}$ of the parental magmatic fluid during crystal growth, as they exhibit additional $\delta^{34} \mathrm{~S}$ fractionation. The shift to more positive $\delta^{34} \mathrm{~S}$ values in late pyrite is consistent with changes in $\mathrm{pH}, \mathrm{H}_{2} \mathrm{~S}: \mathrm{SO}_{4}$, or sulfur disproportionation (below $400{ }^{\circ} \mathrm{C}$, $4 \mathrm{H}_{2} \mathrm{O}+4 \mathrm{SO}_{2} \rightarrow \mathrm{H}_{2} \mathrm{~S}+3 \mathrm{H}^{+}+3 \mathrm{HSO}_{4}^{-}$; Seal 2006), in a liquid phase.

\section{Trace element incorporation in pyrite}

Recent studies utilizing focused ion beam scanning electron microscopy (FIB-SEM) and high-resolution transmission 
electron microscopy (HRTEM) show that nanoscale inclusions $(5-100 \mathrm{~nm})$ of crystalline or amorphous sulfides, sulfosalts and native metals are a common occurrence in hydrothermal pyrite, particularly in pyrite associated with sulfosalt mineralization in high-sulfidation deposits (Deditius et al. 2009, 2011; Pačevski et al. 2012). For example, Pačevski et al. (2012) proved that distinct Pb-rich oscillatory zones in pyrite from the Čoka Marin deposit were formed by rapid co-precipitation of metals, forming zones with abundant nanoscale $\mathrm{Pb}( \pm \mathrm{As}, \mathrm{Ag}, \mathrm{Cu}$ ) inclusions (likely sulfosalts).

In our study, the distribution and concentration of most trace elements is also likely controlled by nanoscale inclusions, given:

(1) The abundance of microscale mineral inclusions (including sulfosalts) and vugs evident within pyrite in reflected light (Fig. 3) and EMPA maps (Fig. 5). In particular, the colloform $\mathrm{Cu}$-rich growth bands in sample EI 1281 (Fig. 5b) correlate with a colloform band of vugs (Fig. 3b). Microscale inclusions in samples EI 2441 and EI 1285 are associated with $\mathrm{Cu}$-rich growth zones (Fig. 5d, e).

(2) Henley et al. (2012) documented a $20-\mu \mathrm{m}$ vug containing $\mathrm{Fe}-$ tennantite and chalcopyrite intergrowths, hosted in early pyrite crystal at El Indio using field emission scanning electron microscopy;

(3) Evidence of $\mathrm{Au}$ and $\mathrm{Bi}$ 'nuggets' in time-resolved LAICP-MS spectra (see Supplementary Table 1), especially considering that the spot size of LA-ICP-MS analyses is $\sim 37 \mu \mathrm{m}$ in diameter;

(4) Extremely poor correlation of trace element abundances with significant changes in $\delta^{34} \mathrm{~S}_{\text {pyrite }}$;

(5) Decoupling of trace element trends across the width of individual crystals. For example, in EI 1281-C (Fig. 8), $\mathrm{Cu}$ is coupled with $\mathrm{Pb}, \mathrm{Ag}, \mathrm{Sb}$ and $\mathrm{Te}$ in the core of the crystal, but not on the outer rims. This may reflect a change in the ratio of nanoscale phases (e.g., sulfosalt/ chalcopyrite inclusions);

(6) Early, massive pyrite crystals precede deposition of sulfosalt melts at El Indio (Henley et al. 2012), creating a parallel to the amorphous 'liquid' nanoscale sulfosalt inclusions observed by Deditius et al. (2009) at the Pueblo Viejo high-sulfidation deposit;

(7) The morphology of early pyrite crystal EI 2441-L (two pentagons with a common edge, Fig. 5d) is suggestive of $\mathrm{FeS}_{2}$ supersaturation, as pyritohedra form under higher degrees of supersaturation than cubic or elongate pyrite crystals (Alonso-Azcarate et al. 2001). If the early pyrite at El Indio formed by supersaturation of the parent fluid as suggested by Henley et al. (2012), this would facilitate deposition of nanoscale inclusions.

(8) The $\mathrm{Cu}$ growth bands in early, massive pyrite crystals EI 2441 and EI 1285 look remarkably similar to the texture of pyrite zonation formed by nanoscale sulfosalt inclusions at the Čoka Marin deposit (Pačevski et al. 2012); however, it should be noted that unlike El Indio, the $\mathrm{Cu}$ is incorporated by solid solution in pyrite from the Čoka Marin deposit.

While the 8 points listed above suggest that nanoscale inclusions may be present, we cannot be certain without additional FIB-SEM or HRTEM analyses that were beyond the scope of this study. We anticipate that syn-depositional inclusions of sulfosalts, chalcopyrite, $\mathrm{Cu}_{2} \mathrm{~S}$, bismuthinites, tellurides, fluorapatite, galena, native metals, kuramite $\left(\sim \mathrm{Cu}_{3} \mathrm{SnS}_{4}\right)$ and $\mathrm{Tl}$ minerals could be present in early, massive pyrite at El Indio, as these minerals have been documented in the surrounding ore assemblage (Henley et al. 2012).

$\mathrm{Co}, \mathrm{Ni}$ and $\mathrm{Mn}$ are the only elements analyzed in this study that cannot be accounted for by discrete minerals previously observed in the El Indio ore assemblage. Coincidentally, $\mathrm{Co}$ and $\mathrm{Ni}$ are the only elements that consistently co-vary in all three samples. $\mathrm{Mn}$ is only $>5 \mathrm{ppm}$ in sample EI 1281, where it correlates with Ni content where it is above detection. These elements each form disulfide end members in the isometric 'pyrite group': cattierite $\left(\mathrm{CoS}_{2}\right)$, vaesite $\left(\mathrm{NiS}_{2}\right)$ and hauerite $\left(\mathrm{MnS}_{2}\right)$. Therefore, it is more likely that $\mathrm{Co}$ and $\mathrm{Ni} \pm \mathrm{Mn}$ are incorporated in the pyrite structure, rather than nanoscale inclusions. Other relevant end members in the isometric 'pyrite group' are villamaninite $(\mathrm{Cu}, \mathrm{Ni}, \mathrm{Co}, \mathrm{Fe}) \mathrm{S}_{2}, \mathrm{AuSb}_{2}, \mathrm{CoSe}_{2}$ and (Ni, Co, Cu)Se $\mathrm{Se}_{2}$ (e.g., Bayliss 1989); however, no convincing evidence for these end members was observed. It is possible that Se may exhibit solid solution in pyrite, but it is also concentrated in sulfosalt mineral inclusions.

Effect of nanoscale inclusions on the interpretation of pyrite geochemistry While nanoscale inclusions greatly affect the abundances of trace elements within pyrite, ionization of sulfide or sulfosalt inclusions during SHRIMP analyses would have little effect on the $\delta^{34} \mathrm{~S}$ of pyrite as they are volumetrically insignificant (comparative surface area of 50-nm-diameter inclusion versus a $20 \times 30 \mu \mathrm{m}$ ion probe pit) and the fractionation between sulfide minerals would be small (e.g., enargite is $2-3.5 \%$ o lighter than pyrite in the El Indio-1 vein; Jannas et al. 1999).

The control of trace element distribution by nanoscale inclusions in pyrite crystals limits the degree of equilibrium-based interpretations on the trace element geochemistry. For example, if the trace element content of a pyrite crystal is controlled by the type and density of nanoscale inclusions, then inferences based on equilibrium partitioning of trace elements in pyrite (i.e., temperature, pressure and redox estimates) cannot be applied. Regardless of whether elements are incorporated into the pyrite structure or present as nanoscale inclusions, trace element 
abundances provide valuable insights into the evolution of mineralizing fluids at El Indio. We consider that the deposition of nanoscale inclusions in high-sulfidation deposit provides a direct record of supersaturation from the parent gas or fluid (e.g., Henley and Berger 2011a; Henley et al. 2012).

\section{Interpretation of $\delta^{34} \mathrm{~S}$ and trace element trends in EI Indio pyrite}

We have established that the trace element content of El Indio pyrite is a product of nanoscale mineral inclusions. Therefore, the trace element content of pyrite does not reflect environmental changes during the growth of pyrite, but passively records a chronological history of cyclical metal saturation in the parent fluid. The significant difference in the range of $\delta^{34} \mathrm{~S}$ between early and late pyrite (Fig. 6) is not easily explained. We interpret the variation in the $\delta^{34} \mathrm{~S}$ of early pyrite as a record of $\delta^{34} \mathrm{~S}$ variability in the parental fluid during deposition from magmatic vapor. As $\mathrm{SO}_{2}$ constitutes the dominant species in the magmatic reservoir, the $\delta^{34} \mathrm{~S}$ of the primary magmatic source should be reasonably constant. The variation in the parental fluid at El Indio is most likely caused by changes in sulfur speciation and chemical reactions between the magmatic reservoir and the fracture array at El Indio. We interpret the shift to more positive $\delta^{34} \mathrm{~S}$ values within late pyrite as evidence for sulfur disproportionation as late pyrite was deposited from a liquid phase, rather than a gas phase. It is possible that $\delta^{34} \mathrm{~S}$ variation in late pyrite may result from changes in $\mathrm{pH}, \mathrm{H}_{2} \mathrm{~S}: \mathrm{SO}_{4}$ as well. It is not yet possible to discriminate these processes based on sulfur isotope or trace element geochemistry in pyrite. It is also unclear whether late pyrite formed from a small volume of acidic liquid condensate exsolved from magmatic vapor, or a large volume of hydrothermal fluid.

Our results demonstrate that minor and trace element zonation (i.e., cyclical saturation of ore metals) in early, massive pyrite, is decoupled from large changes in the $\delta^{34} \mathrm{~S}$ of the parental fluid. This suggests that fluids in high-sulfidation environments undergo cyclical changes in fluid pressure, causing sporadic saturation in metals (perhaps evidenced by oscillatory zonation of syn-depositional, nanoscale mineral inclusions). Such small, local changes in fluid pressure are not great enough to shift the bulk $\mathrm{SO}_{2}: \mathrm{H}_{2} \mathrm{~S}$ of the parent fluid. The variations in $\delta^{34} \mathrm{~S}$ in early, massive pyrite are likely inherited from changes in the parent fluid at greater depth. Further studies are required to constrain the genetic processes controlling the sulfur isotope signature of late pyrite at El Indio.

\section{Implications for mineralization and mineral exploration}

As both crystals of early pyrite from high-temperature feeder zones exhibited distinct $\mathrm{Cu}$-rich zonation (interpreted as cyclical saturation of nanoscale $\mathrm{Cu}$ minerals), we suggest that as part of a detailed geological study, identification of $\mathrm{Cu}$-zoned pyrite could be used as a pathfinder in high-sulfidation deposits to target subsequent high-grade $\mathrm{Cu}$ mineralization (in this case, enargite) located in feeder zones. The absolute $\mathrm{Cu}$ content of the pyrite would not necessarily show this, so EMPA maps (or similar techniques) would be required to assess the prospectivity of pyrite crystals. It is interesting that pyrite crystals at the Pascua-Lama deposit, $550 \mathrm{~km}$ north of El Indio (Chouinard et al. 2005), showed cyclical enrichment of both $\mathrm{Au}$ and $\mathrm{Cu}$ during the same paragenetic stage, implying a fundamental difference in the evolution of their respective source fluids.

The recent literature documenting the effect of syn-depositional nanoscale sulfosalt inclusions in controlling the trace element content of pyrite is derived from studies of polymetallic, high-sulfidation-style deposits (Deditius et al. 2009, 2011; Pačevski et al. 2012). As these deposits are relatively unique in their concentration of sulfosalt minerals, trace element control by nanoscale sulfosalt inclusions may be a process restricted to these styles of deposits.

Our work is a preliminary study into coupled trace element and sulfur isotope geochemistry in pyrite. In order to apply these findings more widely, further work needs to be done to understand intracrystalline variations in pyrite geochemistry.

\section{Conclusions}

We compared the in situ isotopic and trace element chemistry of early, massive pyrite crystals hosting enargite-tennantite mineralization from high-temperature feeder zones with late pyrite, formed during $\mathrm{Au}$-stage mineralization and extensive silicification at the El Indio $\mathrm{Au}-\mathrm{Cu}-\mathrm{Ag}$ deposit, Chile. Our study revealed complex intracrystalline zonation of $\delta^{34} \mathrm{~S}$ of up to $4.48 \%$; poor correlation between trace elements; and no correlation between trace elements and the $\delta^{34} \mathrm{~S}$ of pyrite.

We attribute the $\delta^{34} \mathrm{~S}$ values in early pyrite from hightemperature feeder zones to sublimation from ascending magmatic vapor. Intracrystalline variation in the $\delta^{34} S$ of early pyrite is inherited from changes in the parent fluid at depth, while variation in most trace elements is controlled by nanoscale mineral inclusions formed during cyclical changes in fluid pressure. 
The $\delta^{34} \mathrm{~S}$ values in late pyrite associated with Au-stage mineralization and extensive silicification indicate that late pyrite was deposited from a liquid phase rather than a gas phase. Intracrystalline variation of $\delta^{34} S$ in late pyrite cannot be explained by changes in the $\delta^{34} \mathrm{~S}$ of a parental magmatic fluid, but instead the shift to more positive $\delta^{34} \mathrm{~S}$ values records changes in sulfur disproportionation and/or changes in $\mathrm{pH}, \mathrm{H}_{2} \mathrm{~S}: \mathrm{SO}_{4}$. The trace elements in late pyrite also appear to be dominantly controlled by nanoscale inclusions. Whether late pyrite was formed from a small volume of acidic condensate or a larger volume of hydrothermal fluid remains unresolved.

Our results suggest that the distinctive $\mathrm{Cu}$ zoning observed in early pyrite preceding enargite-tennantite mineralization at El Indio could be a useful pathfinder in mineral exploration for targeting high-grade feeder zones. Given that the literature documenting syn-depositional nanoscale inclusions is largely from polymetallic, highsulfidation-style deposits, the incorporation of nanoscale inclusions may be restricted to pyrite crystals from these styles of deposits.

Acknowledgments D. Tanner acknowledges the support of an APA scholarship and an SEG student fellowship, as well as the overwhelming support of her Ph.D. supervisors while she worked abroad. F. Brink, R. Rapp, C. Allen and F. Jenner are thanked for their technical support in running the SEM, EMPA and LA-ICP-MS, respectively. F. Robert and C. Tellez of Barrick Gold Corporation are thanked for providing the sample material. The authors would like to acknowledge S. Cox for advising the use of concentrated bleach as an etchant, and R. Armstrong for providing the Ruttan pyrite standard. We thank J. Ward for her comments on this manuscript. The Australian Research Council and Newcrest Mining are thanked for their financial support. We thank A. Pačevski, M. Fiorentini and two anonymous reviewers for very useful and detailed comments, which greatly improved our manuscript.

Open Access This article is distributed under the terms of the Creative Commons Attribution 4.0 International License (http://creativecommons.org/licenses/by/4.0/), which permits unrestricted use, distribution, and reproduction in any medium, provided you give appropriate credit to the original author(s) and the source, provide a link to the Creative Commons license, and indicate if changes were made.

\section{References}

Alonso-Azcarate J, Roads M, Fernadez-Diaz L, Bottrell S, Mas J, Lopez-Andres S (2001) Causes of variation in crystal morphology in metamorphogenic pyrite deposits of the Cameros bason (N Spain). Geol J 36:159-170

Arribas A, Cunningham C, Rytuba J, Rye R, Kelly W, Podwysocki M, McKee E, Tosdal R (1995) Geology, geochronology, fluid inclusions and isotope geochemistry of the Rodalquilar gold alunite deposit, Spain. Econ Geol 90:795-822

Barker S, Hickey K, Cline J, Dipple G, Kilburn M, Vaughan J, Longo A (2009) Uncloaking invisible gold: use of NANOSIMS to evaluate gold, trace elements and sulfur isotopes in pyrite from Carlin-type gold deposits. Econ Geol 104:897-904
Bayliss A (1989) Crystal chemistry and crystallography of some minerals within the pyrite group. Am Mineral 74:1168-1176

Berger BR, Henley RW (2011) Magmatic-vapor expansion and the formation of high-sulfidation gold deposits: Structural controls on hydrothermal alteration and ore mineralization. Ore Geol Rev 39:75-90. doi:10.1016/j.oregeorev.2010.11.004

Bethke P, Rye R, Stoffregen R, Vikre P (2005) Evolution of the magmatic-hydrothermal acid-sulfate system at Summitville, Colorado: integration of geological, stable-isotope, and fluid-inclusion evidence. Chem Geol 215:281-315

Borojević Šoštarić S, Palinkaš L, Topa D, Spangenberg J, Prochaska W (2011) Silver-base metal epithermal vein and listwaenite types of deposit Crnac, Rogozna Mts., Kosovo. Part I: ore mineral geochemistry and sulfur isotope study. Ore Geol Rev 40:65-80

Cerpa L, Bissig T, Kyser K, McEwan C, Macassi A, Rios H (2013) Lithologic controls on mineralization at the Lagunas Norte highsulfidation epithermal gold deposit, northern Peru. Miner Deposita 48:653-673

Chouinard A, Paquette J, Williams-Jones A (2005) Crystallographic controls on trace element incorporation in auriferous pyrite from the Pascua epithermal high-sulfidation deposit Chile-Argentina. Can Mineral 43:951-963

Cox S (1987) Flow mechanisms in sulphide minerals. Ore Geol Rev 2:133-171

Craig JR, Vokes FM, Solberg TN (1998) Pyrite: physical and chemical textures. Miner Depos 34:82-101. doi:10.1007/s001260050187

Deditius A, Utsunomiya S, Ewing R, Kesler S (2009) Nanoscale "liquid" inclusions of $\mathrm{As}-\mathrm{Fe}-\mathrm{S}$ in arsenian pyrite. Am Mineral 94:391-394

Deditius A, Utsunomiya S, Reich M, Kesler S, Ewing R, Hough R, Walshe J (2011) Trace metal nanoparticles in pyrite. Ore Geol Rev 42:32-46

Deyell C, Bissig T, Rye R (2004) Isotopic evidence for magmaticdominated epithermal proceses in El Indio-Pascua $\mathrm{Au}-\mathrm{Cu}-\mathrm{Ag}$ belt and relationship to geomorphologic setting. Soc Econ Geol Spec Pub 11:55-73

Deyell C, Rye R, Landis G, Bissing T (2005a) Alunite and the role of magmatic fluids in the Tambo high-sulfidation deposit, El IndioPascua belt, Chile. Chem Geol 215:185-218

Deyell C, Leonardson R, Rye R et al (2005b) Alunite in the PascuaLama high-sulfidation deposit: constraints on alteration and ore deposition using stable isotope geochemistry. Econ Geol 100:131-148

Fifarek R, Rye R (2005) Stable-isotope geochemistry of the Pierina high-sulfidation $\mathrm{Au}-\mathrm{Ag}$ deposit, Peru: influence of hydrodynamics on $\mathrm{SO}_{4}{ }^{2-}-\mathrm{H}_{2} \mathrm{~S}$ sulfur isotopic exchange in magmatic-steam and steam-heated environments. Chem Geol 215:253-279

Franchini M, McFarlane C, Maydagán L et al (2015) Trace metals in pyrite and marcasite from the Agua Rica porphyry-high sulfidation epithermal deposit, Catamarca, Argentina: textural features and metal zoning at the porphyry to epithermal transition. Ore Geol Rev 66:366-387

Henley R, Berger B (2011a) Magmatic-vapor expansion and the formation of high-sulfidation gold deposits: chemical controls on alteration and mineralization. Ore Geol Rev 39:75-90

Henley R, Berger B (2011b) Pyrite-sulfosalt reactions and semimetal fractionation in the Chinkuashih, Taiwan, copper-gold deposit: a 1 Ma paleo-fumarole. Geofluids 12:245-260

Henley R, Mavrogenes J, Tanner D (2012) Sulfosalt melts and heavy metal (As-Sb-Bi-Sn-Pb-Tl) fractionation during volcanic gas expansion: the El Indio (Chile) paleo-fumarole. Geofluids 12:199-215

Henley R, King P, Wykes J, Renggli C, Brink F, Clark D, Troitzch U (2015) Porphyry copper deposit foration by sub-volcanic sulphur dioxide flux and chemisorption. Nat GeoSci 8:210-215 
Holden P, Ireland T (2011) Measuring 4 isotope sulfur on SHRIMPSI. 6th Biennial Geochemical SIMS Workshop, Outrigger Reef Hotel, Waikiki, 2-4 November 2011. Available at: www.higp. hawaii.edu/bgsw6/Abstracts_posters_BGSW6.pdf

Holden P, Armstrong R, Foster J, Lanc P, Schram N, Ireland T (2012) Measurement of four-isotope sulfur ratios on SHRIMP-SI. Mineral Mag 76:1037

Huston DL, Sie SH, Suter GF et al (1995) Trace elements in sulfide minerals from eastern Australian volcanic- hosted massive sulfide deposits: part I. Proton microprobe analyses of pyrite, chalcopyrite, and sphalerite, and part II. Selenium levels in pyrite: comparison with $\delta 34 \mathrm{~S}$ values and impl. Econ Geol 90:1167-1196

Ireland T, Clement S, Compston W et al (2008) Development of SHRIMP. Aust J Earth Sci 55:937-954

Jannas RR (1995) Reduced and oxidized high sulfidation deposits of the El Indio district, Chile. PhD Thesis, Harvard University

Jannas R, Beane R, Ahler B, Brosnahan D (1990) Gold and copper mineralization at the El Indio deposit, Chile. J Geochem Explor 36:233-266

Jannas R, Bowers T, Petersen U, Beane R (1999) High-sulfidation deposit types in the El Indio district, Chile. Soc Econ Geol Spec Pub 7:219-266

Juliani C, Rye R, Nunes C, Snee L, Corrêa Silva R, Monteiro L, Bettencourt J, Neumann R, Neto A (2005) Paleoproterozoic high-sulfidation mineralization in the Tapajós gold province, Amazonian Craton, Brazil: geology, mineralogy, alunite argon age, and stable-isotope constraints. Chem Geol 215:95-125

King J, Williams-Jones A, van Hinsberg V, Williams-Jones G (2014) High-sulfidation epithermal pyrite-hosted $\mathrm{Au}(\mathrm{Ag}-\mathrm{Cu})$ ore formation by condensed magmatic vapors on Sangihe Island, Indonesia. Econ Geol 109:1705-1733

Lach P, Cathelineau M, Brouand M, Fiet N (2015) In-situ isotopic and chemical study of pyrite from Chu-Sarysu (Kazakhstan) rollfront uranium deposit. Procedia Earth Planet Sci 13:207-210

Landis G, Rye R (2005) Characterization of gas chemistry and noblegas isotope ratios of inclusion fluids in magmatic-hydrothermal and magmatic-steam alunite. Chem Geol 215:155-184

Longerich H, Jackson S, Gunther D (1996) Laser ablation inductively coupled plasma mass spectrometric transient signal data acquisition and analyte concentration calculation. J Anal Atom Spectrom 11:899-904

Madyagan L, Franchini M, Lentz DR et al (2013) Sulfide composition and isotopic signature of the Altar $\mathrm{Cu}-\mathrm{Au}$ deposit, Argentina: constraints on the evolution of the porphyry-epithermal system. Can Mineral 51:813-840

Mavrogenes J, Henley RW, Reyes AG, Berger B (2010) Sulfosalt melts: Evidence of high-temperature vapor transport of metals in the formation of high-sulfidation lode gold deposits. Econ Geol 105:257-262. doi:10.2113/gsecongeo.105.2.257

Murray A (2011) Hydrothermal alteration, ore fluid characteristics and mechanisms for gold deposition at the Wallaby Gold Deposit, Laverton, Western Australia. Honours thesis, Australian National University

Ohmoto H, Rye R (1979) Isotopes of sulfur and carbon. In: Barnes H (ed) Geochemistry of hydrothermal ore deposits, 2nd edn. Wiley, New York, pp 509-567

Oppenheimer C, Scaillet B, Martin R (2011) Sulfur degassing from volcanoes: source conditions, surveillance, plume chemistry and earth system impacts. Rev Mineral Geochem 73:363-421

Pačevski A, Moritz R, Kouzmanov K, Marquardt K, Zivkovic P, Cvetkovic L (2012) Texture and composition of Pb-bearing pyrite from the Čoka Marin polymetallic deposit, Serbia, controlled by nanoscale inclusions. Can Mineral 50:1-20

Paton C, Hellstrom J, Paul B, Woodhead J, Hergt J (2011) Iolite: freeware for the visualization and processing of mass spectrometer data. J Anal Atom Spectrom 26:2508-2518

Peterson E, Mavrogenes J (2014) Linking high-grade gold mineralization to earthquake-induced fault-valve processes in the Porgera gold deposit, Papua New Guinea. Geology 42:383-386

Seal RR (2006) Sulfur isotope geochemistry of sulfide minerals. Rev Mineral Geochem 61:633-677

Tanner D, Henley R, Mavrogenes J, Holden P (2013) Combining in situ isotopic, trace element and textural analyses of quartz from four magmatic-hydrothermal ore deposits. Contrib Mineral Petrol 166:1119-1142

Tanner D, Henley R, Mavrogenes J, Holden P, Mernagh T (2015) Cryptic silica hydrate: a common precursor to high-temperature hydrothermal quartz? Chem Geol 391:90-99

Taylor H (1979) Oxygen and hydrogen isotope relationships in hydrothermal mineral deposits. In: Barnes $\mathrm{H}$ (ed) Geochemistry of hydrothermal ore deposits, 2nd edn. Wiley, New York, pp 236-277

Ulrich T, Long DGF, Kamber BS, Whitehouse MJ (2011) In situ trace element and sulfur isotope analysis of pyrite in a paleoproterozoic gold placer deposit, pardo and clement townships, Ontario, Canada. Econ Geol 106:667-686

Whitehouse M (2013) Multiple sulfur isotope determination by SIMS: evaluation of reference sulfides for $\Delta^{33} S$ with observations and a case study on the determination of $\Delta^{36} \mathrm{~S}$. Geostand Geoanal Res 37:19-33

Xue Y, Campbell I, Ireland TR et al (2013) No mass-independent sulfur isotope fractionation in auriferous fluids supports a magmatic origin for Archean gold deposits. Geology 41:791-794 